\title{
PERFORMANCE OF DIFFERENT LUMINESCENCE APPROACHES FOR THE DATING OF KNOWN-AGE GLACIOFLUVIAL DEPOSITS FROM NORTHERN SWITZERLAND
}

\author{
DORIAN GAAR ${ }^{1}$, SALLY E. LOWICK ${ }^{1}$ and FRANK PREUSSER ${ }^{2}$ \\ ${ }^{l}$ Institute of Geological Sciences and Oeschger Centre for Climate Change Research, University of Bern, \\ Baltzerstrasse 1+3, 3012 Bern, Switzerland \\ ${ }^{2}$ Department of Physical Geography and Quaternary Geology, Stockholm University, 10691 Stockholm, Sweden
}

Received 26 March 2013

Accepted 26 August 2013

\begin{abstract}
Luminescence properties of two samples taken from sand lenses in proglacial outwash deposits of a piedmont glacier that reached the Swiss midlands during the Last Glacial Maximum are investigated in detail. Deconvolution of CW-OSL decay curves shows that the fast component dominates the OSL signal of quartz. The chemistry of single feldspar grains, in particular the $\mathrm{K}$ content in different grains, is determined using wavelength dispersive spectrometry (electron microprobe), revealing an average $12.9 \mathrm{wt} . \% \mathrm{~K}$ of the grains contributing to the IRSL signal. $D_{e}$ distributions are investigated in order to gain insights into partial bleaching, and agreement is found for quartz OSL and feldspar $\mathrm{IR}_{50}$ and $\mathrm{pIRIR}_{225}$ ages for small aliquots and single grains when applying the Minimum Age Model. These ages are also consistent with independent age control. For one sample, ages determined using the Central Age Model result in highly overestimated ages for both feldspar and quartz.
\end{abstract}

Keywords: partial bleaching, single grains, dose distributions, quartz, K-feldspar, potassium content.

\section{INTRODUCTION}

Natural outcrops and numerous gravel pits composed of till and glaciofluvial deposits in the northern Swiss lowlands represent one of the most complex archives of the Quaternary glaciation history. Graf (2009) defined corresponding sedimentary units by means of lithostratigraphy and identified five Middle to Late Pleistocene glaciations named Möhlin, Habsburg, Hagenholz, Beringen, and Birrfeld (cf. Preusser et al., 2011). The latter glaciation is correlated to the Late Pleistocene and most likely comprises at least three independent glacial advances followed by deglaciation of the foreland (e.g. Ivy-Ochs et al., 2008; Preusser et al., 2011). However, while the relative chro-

Corresponding author: D. Gaar

e-mail: gaar@geo.unibe.ch nology has been established, there is an urgent need for a reliable numerical chronology for the region to allow correlations with global climatic developments.

A method for dating Pleistocene deposits is radiocarbon which provides precise ages for organic matter found within sediments. Nevertheless, there is usually a lack of organic matter within glaciofluvial sediments and the upper age limit of around $50 \mathrm{ka}$ further limits the application of radiocarbon dating (Hajdas, 2009). Luminescence dating has proven to be a robust method for dating a variety of sediments from different environmental settings (Preusser et al., 2008). Generally two minerals, quartz and potassium-rich feldspar, are used as dosimeters for luminescence dating. When dating quartz the term optically stimulated luminescence (OSL) is used, as stimulation is made by visible blue light. Commonly for feld- 
spar dating, infrared stimulated luminescence (IRSL) is used. Two methods are applied in this article for feldspar dating: IRSL at $50^{\circ} \mathrm{C}\left(\mathrm{IR}_{50}\right)$ and IRSL at $225^{\circ} \mathrm{C}$ following $\mathrm{IR}_{50}(\mathrm{pIRIR} 225)$. A basic pre-requisite of luminescence dating is the resetting of the signal by sunlight prior to deposition. However, the dating of glacier related deposits still bears some methodological difficulties as this requirement is not always fulfilled. Due to short distance transport and the usually high sediment load, the probability of resetting the latent signal in sediment grains transported by glacial melt-water streams is much lower compared to, for example, aeolian transport (e.g. Fuchs and Owen, 2008; Thrasher et al., 2009). This can lead to only partial bleaching of the luminescence signal in the sediment grains and result in overestimation of the apparent luminescence ages. Duller (1994) pointed out that in natural sedimentary systems the luminescence signal will be removed to different residual levels in each individual grain, including grains where the signal is completely removed.

To overcome the problem of partial bleaching various approaches have been developed. One approach is to identify sediments in a section which are likely to be well bleached based on their transport and sedimentation history, and hence glacioaeolian sediments would be preferred over till (e.g. Fuchs and Owen, 2008). However, not all outcrop situations offer a variety of sediment types. Hence, other approaches are required to identify the presence of partial bleaching in samples and determine the burial age. One way of doing so is to measure a large number of aliquots each containing only a few grains. This lowers the averaging effects observed in large aliquots with hundreds to thousands of grains, and increases the chance to isolate completely reset grains (Wallinga, 2002a). Ideally, one would measure individual single grains, but this may be hampered by low numbers of grains exhibiting suitable luminescence signals, often seen in the case of quartz OSL, and hence may be far more time consuming than measuring single aliquots with few grains (Duller, 2008). From the distribution of equivalent doses $\left(D_{e}\right)$ measured, the completely reset population of grains/aliquots at the lower edge of the distribution is extracted using statistical models, such as the 'Minimum Age Model' (MAM; Galbraith et al., 1999); presently the most commonly used approach. All statistical models depend on certain input parameters, for example the expected overdispersion in the case of the MAM, and the proper selection of such parameters can be problematic (Galbraith and Roberts, 2012). In addition, one has to firstly identify whether partial bleaching is actually present in the sample, in order to choose the appropriate statistical model. To do so, Murray et al. (2012) have suggested using the comparison of quartz and feldspar palaeodoses to identify well bleached samples, expecting the OSL signal in quartz to bleach more rapidly than the IRSL in feldspar. This test needs to be applied to large aliquots, and thus on average signals, as other sources of scatter (e.g. dose rate heterogeneity) must be excluded.

As indicated above the two minerals used for luminescence dating have differing characteristics. Quartz has been proven to be a reliable dosimeter in many studies (cf. Preusser et al., 2009), but commonly saturates at relatively low doses and therefore has a limited dating range. Furthermore, the sensitivity (signal intensity) of quartz OSL can be too low to allow for proper detection, as observed, for example, for bedrock samples and glaciofluvial sediments from the South Island of New Zealand (Preusser et al., 2006; Rowan et al., 2012). However, while feldspar can accumulate much larger doses compared to quartz, it is thought to have a lower bleaching rate according to experiments carried out by GodfreySmith et al. (1988) using a green laser. Fuller et al. (1994) therefore proposed that dating of glaciofluvial sediments should be restricted to quartz. A more rapid resetting of quartz OSL compared to feldspar $\mathrm{IR}_{50}$ has also been observed by Thomsen et al. (2008) when using a solar simulator in the experiments. In contrast, Preusser (1999a) and Klasen et al. (2006) found that the signal resetting behaviour of coarse grain quartz and feldspar were alike when tested under light conditions similar to natural fluvial environments. Another problem related to feldspar is the loss of signal over time, referred to as anomalous fading (Wintle, 1973; Spooner, 1994). When fading is present in feldspar, the age of a sample will be underestimated. While approaches to determine fading rates and correct feldspar ages have been suggested (Huntley and Lamothe, 2001; Auclair et al., 2003), these have sometimes been shown to be problematic, also for samples from the Swiss Alpine foreland (Gaar and Preusser, 2012; Lowick et al., 2012). Alternatively it has been proposed to reduce the problem of fading by using a more stable signal such as the post-infrared-infrared stimulated luminescence (pIRIR; Thomsen et al., 2008; Buylaert et al., 2009). This signal however can have significantly larger residuals and requires a better understanding of their origin (Stevens et al., 2011; Lowick et $a l ., 2012)$; some work on the better understanding of residuals has been published lately (e.g. Qin and Zhou, 2012; Sohbati et al., 2012). A first study testing the potential of pIRIR for proglacial sediments by Blomdin et al. (2012) showed clear evidence for severe incomplete bleaching for samples from Patagonia.

In the above context, there is considerable debate with regard to the levels of partial bleaching present in proglacial sediments. For example, Alexanderson and Murray (2012) concluded that the problem of age overestimation due to partial bleaching was restricted to very proximal (less than $1 \mathrm{~km}$ transported from ice front) modern sediments from Svalbard. For Pleistocene samples from Arctic Russia, Thomas et al. (2006) argue that partial bleaching is not expected to be a problem and this has led others to generally adopt this assumption and to not investigate proglacial samples for partial bleaching. 
In contrast, Klasen et al. (2007) and Preusser et al. (2007) report clear indications for partial bleaching and age overestimation for sites in Austria and in the Swiss Alpine foreland, respectively, determined from both dose distributions, as well as comparison with independent age control. This controversy has been highlighted by two recent studies along the Hochrhein, i.e. the Rhine Valley between Lake Constance and Basel. Kock et al. (2009) determined quartz OSL ages for glaciofluvial sediments between $15 \mathrm{ka}$ and $30 \mathrm{ka}$, hence ages corresponding with the time of the last presence of glaciers in the Alpine foreland. On the other hand, Frechen et al. (2010) yielded significantly higher quartz OSL ages, in part from the same outcrops, and concluded a deposition prior to the last glaciation. The difference in the ages has been explained by partial bleaching (cf. Frechen et al., 2012; Preusser et al., 2012), which was deduced by Kock et al. (2009) from the $D_{e}$ distributions, but was assumed not to be 'dramatic' by Frechen et al. (2010). The major difference between the two studies is that Kock et al. (2009) used small ( $2 \mathrm{~mm}$ ) aliquots whereas Frechen et al. (2010) utilised large aliquots $(8 \mathrm{~mm})$, where averaging effects do not allow the detection of partial bleaching.

In the present study, different approaches of palaeodose estimation are investigated on two samples from one outcrop of glaciofluvial sediments of the Swiss Alpine foreland, for which independent age constraints are available. The aim is to compare the suitability of the different approaches and use this information in forthcoming studies in the same region for the dating of similar sediments of unknown age. As both quartz and feldspar offer advantages and disadvantages, we investigate the luminescence properties of coarse grains $(200-250 \mu \mathrm{m})$ of both minerals (OSL signal component analyses, fading tests). The internal potassium content of the feldspar grains is also determined. A special focus was given to analysis of dose distributions with regard to partial bleaching, and the comparison of quartz OSL with feldspar $\mathrm{IR}_{50}$ and pIRIR $_{225}$ ages.

\section{SITE AND SAMPLE DESCRIPTION}

The test site is located in central northern Switzerland near the villages of Gebenstorf and Turgi (Fig. 1), between the rivers Reuss and Limmat, next to the confluence of the Rivers Reuss and Aare. The two samples investigated (GE 2 and GE 3), originate from the gravel pit "Geelig" located within the low terrace which is attributed to the Last Glacial Maximum (LGM), the main advance of the Birrfeld glaciation (Graf, 2009). The glacier reached a position $c a .5 \mathrm{~km}$ upstream of the sampling location during the LGM (Fig. 1b), which is indicated by a terminal moraine.

From other sites, it is known that the foreland of the Swiss Alps was ice free until ca. $30 \mathrm{ka}$ ago and that glaciers had disappeared from the area prior to $17.5 \mathrm{ka}$ (cf. Preusser et al., 2011). Peat and overbank deposits in the former gravel pit of Gossau (which is $45 \mathrm{~km}$ southeast of the sampling site towards the Alps) have been dated to $30 \mathrm{ka}$ using radiocarbon, Uranium series and OSL/IRSL. They are overlain by outwash sediments attributed to the LGM and provide a first age constraint with an upper age limit for our samples (Schlüchter et al., 1987; Preusser, 1999b; Preusser et al., 2003).

Independent age control for the Gebenstorf site is additionally provided by a radiocarbon age of a mammoth molar which was stored in the palaeontological museum of the University of Zürich. As its label, named the village Turgi as the locality, and the gravel pit "Geelig" is the only pit in the area during historic times, it is attributed to the same gravel pit our samples originate from (Graf, 2009). AMS radiocarbon dating (ETH-17256) yielded $18,150 \pm 140{ }^{14} \mathrm{C} \mathrm{BP}$, which corresponds to a calibrated age range of 22.09 to $21.45 \mathrm{ka} \mathrm{b2k}$ using OxCal 4.1 (Bronk Ramsey, 2009) applying the IntCal09 calibration curve of Reimer et al. (2009). However, it has been shown that the dating of bone material can be problematic with regard to later contamination with young humic acids (Hajdas et al., 2009) and we therefore consider that the age may represent a minimum estimate.

Fig. 2 shows the outcrop face of approximately $12 \mathrm{~m}$ height where samples were taken. The succession consists mainly of glaciofluvial gravel intercalated with sand lenses of which some have an erosive base. Their thickness varies and can reach several decimetres. The samples were taken from two sand lenses of around $40 \mathrm{~cm}$ thickness, vertically centred, so the risk of inhomogeneous radiation fields is considered to be small. Both sand lenses have a similar appearance and are interpreted to originate from the same sedimentary depositional environment, i.e. sandy fills of shallow channels of a former braided river system that was fed by melt-water originating from a glacier.

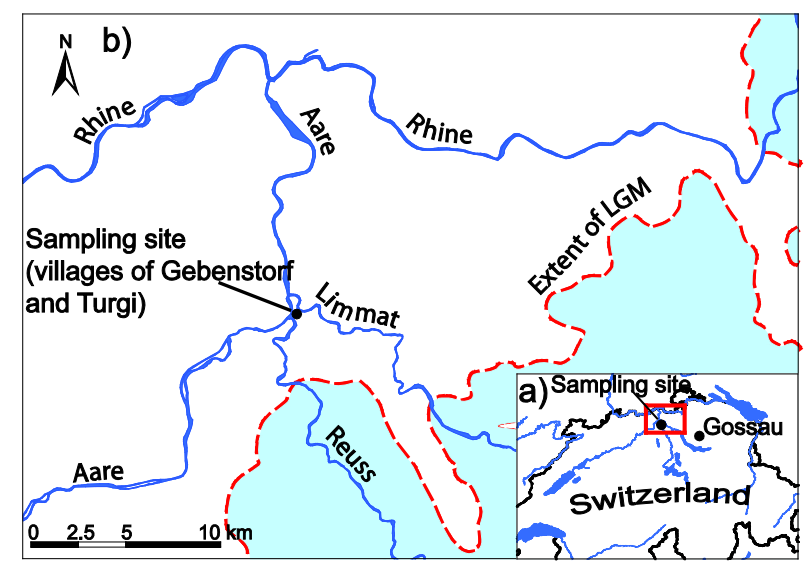

Fig. 1. a) Overview of Switzerland with the sites mentioned in the text. The rectangle indicates extent of map b) which shows the location of the sampling site at Gebenstorf and Turgi between the rivers Reuss and Limmat, next to the confluence of the Rivers Reuss and Aare. Shaded area with the dashed line marks the extent of the ice during the Last Glacial Maximum (adopted from Bini et al. (2009)). 


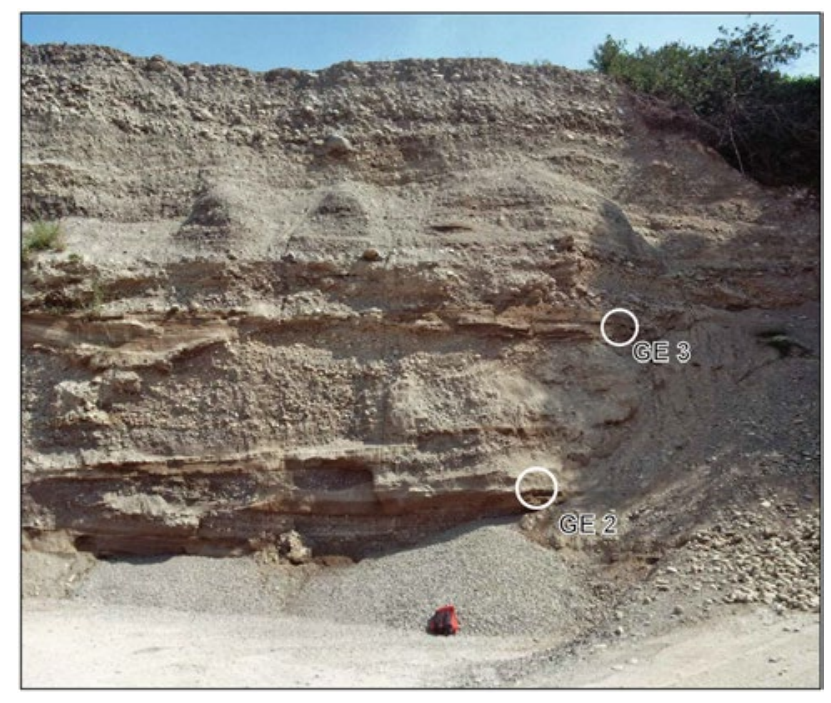

Fig. 2. View of the sampling face. Total height of the outcrop is ca. $12 \mathrm{~m}$..

\section{METHODOLOGY}

\section{Sampling and sample preparation}

For sampling, the surface of the outcrop was cleaned and steel tubes were forced into the sediment instantaneously. The samples were emptied into opaque plastic bags avoiding any sunlight exposure. Sample preparation was carried out under subdued red-light conditions in the laboratory. The $200-250 \mu \mathrm{m}$ fraction was separated by dry sieving. Chemical cleaning consisted of treatments with $\mathrm{HCl}(32 \%)$ and $\mathrm{H}_{2} \mathrm{O}_{2}(30 \%)$ to remove carbonates and organics, respectively. This was followed by density separation $\left(2.70\right.$ and $\left.2.58 \mathrm{~g} \mathrm{~cm}^{-3}\right)$ to obtain a quartz-rich and K-feldspar-rich fraction. The quartz fraction was then etched for $60 \mathrm{~min}$ in HF (40\%) to remove any remaining feldspar and the outer rim of the quartz grains, followed by another $\mathrm{HCl}$ treatment to dissolve fluoride precipitates formed during the HF treatment.

For the luminescence measurements the samples were mounted on stainless steel discs using silicone spray with the aliquot size determined by masks. Aliquot sizes of $6 \mathrm{~mm}$ and $2 \mathrm{~mm}$ were used for the quartz, $6 \mathrm{~mm}, 2 \mathrm{~mm}$ (in one case for pIRIR) and $1 \mathrm{~mm}$ for feldspar, respectively. The different sizes were chosen in order to compare the influence of aliquot size on palaeodose estimation. The average number of grains were counted to be $300(6 \mathrm{~mm}), 50(2 \mathrm{~mm}), 30(1 \mathrm{~mm})$ for the different aliquot sizes.

Single grains were measured on aluminium discs with $10 \times 10$ holes of $300 \mu \mathrm{m}$ both in diameter and depth. Single grains were mounted by brushing an excess number of grains over the disc. The chosen grain size (200$250 \mu \mathrm{m})$ ensures only one grain per hole. We performed the mounting under a binocular and scrutinised proper placement of the grains in the holes; on average $90 \%$ of the holes were filled.

\section{Equipment and equivalent dose determination}

Luminescence measurements were made on automated Risø TL/OSL DA-20 readers equipped with 9235QA photomultiplier tubes. For single grain measurements a Risø single grain laser attachment with dual lasers was used. The $\beta$-source in the single grain reader has been checked for inhomogeneity of its irradiation field, as this can be of importance for the single grain measurements. Applying the method proposed by Lapp et al. (2012) using a $\beta$-radiation sensitive self-developing film it was concluded that non-uniformity of the $\beta$-source is minor and hence no correction on the single grains measurements was applied.

Palaeodoses were determined using a modified singlealiquot regenerative-dose (SAR) protocol after Murray and Wintle (2000) (Table 1). Several equivalent dose

Table 1. Protocols used in this study. OSL was applied to quartz, IR50 and pIRIR225 were applied to feldspar. OSL: stimulation with blue LEDs, SG OSL with a green laser, IRSL: stimulation with IR LEDS, SG IRSL with an IR laser. ${ }^{1}$ Omitted in 1 st cycle to measure Ln, ${ }^{2}$ only applied in last cycle.

\begin{tabular}{|c|c|c|c|c|c|c|}
\hline Observed & $\begin{array}{l}\text { OSL - multiple } \\
\text { grain aliquots }\end{array}$ & $\begin{array}{l}\text { OSL - single } \\
\text { grains }\end{array}$ & $\begin{array}{l}\text { IR } 50 \text { - multiple } \\
\text { grain aliquots }\end{array}$ & $\begin{array}{l}\mathrm{IR}_{50} \text { - single } \\
\text { grains }\end{array}$ & $\begin{array}{l}\text { postlRIR225- } \\
\text { multiple grain } \\
\text { aliquots }\end{array}$ & $\begin{array}{l}\text { postlRIR } 225- \\
\text { single grains }\end{array}$ \\
\hline & ${ }^{1}$ Dose & ${ }^{1}$ Dose & ${ }^{1}$ Dose & ${ }^{1}$ Dose & 1Dose & ${ }^{1}$ Dose \\
\hline & $\begin{array}{c}\text { Preheat at } 230^{\circ} \mathrm{C} \\
\text { for } 10 \mathrm{~s}\end{array}$ & $\begin{array}{c}\text { Preheat at } 230^{\circ} \mathrm{C} \\
\text { for } 10 \mathrm{~s}\end{array}$ & $\begin{array}{c}\text { Preheat at } 230^{\circ} \mathrm{C} \\
\text { for } 60 \mathrm{~s}\end{array}$ & $\begin{array}{c}\text { Preheat at } 230^{\circ} \mathrm{C} \\
\text { for } 60 \mathrm{~s}\end{array}$ & $\begin{array}{c}\text { Preheat at } 250^{\circ} \mathrm{C} \\
\text { for } 60 \mathrm{~s}\end{array}$ & $\begin{array}{c}\text { Preheat at } 230^{\circ} \mathrm{C} \\
\text { for } 60 \mathrm{~s}\end{array}$ \\
\hline & $\begin{array}{l}{ }^{2} \mathrm{IRSL} \text { at } 50^{\circ} \mathrm{C} \\
\text { for } 60 \mathrm{~s}\end{array}$ & $\begin{array}{c}{ }^{2} \mathrm{SG} \mathrm{IRSL} \text { at } 50^{\circ} \mathrm{C} \\
\text { for } 5 \mathrm{~s}\end{array}$ & & & $\begin{array}{l}\mathrm{IRSL} \text { at } 50^{\circ} \mathrm{C} \\
\text { for } 100 \mathrm{~s}\end{array}$ & $\begin{array}{l}\mathrm{IRSL} \text { at } 50^{\circ} \mathrm{C} \\
\text { for } 100 \mathrm{~s}\end{array}$ \\
\hline \multirow[t]{4}{*}{$\operatorname{Ln} / \operatorname{Lx}$} & $\begin{array}{l}\mathrm{OSL} \text { at } 125^{\circ} \mathrm{C} \\
\text { for } 60 \mathrm{~s}\end{array}$ & $\begin{array}{c}\mathrm{SG} \mathrm{OSL} \text { at } 125^{\circ} \mathrm{C} \\
\text { for } 5 \mathrm{~s}\end{array}$ & $\begin{array}{c}\text { IRSL at } 50^{\circ} \mathrm{C} \\
\text { for } 300 \mathrm{~s}\end{array}$ & $\begin{array}{l}\text { SG IRSL at } 50^{\circ} \mathrm{C} \\
\text { for } 5 \mathrm{~s}\end{array}$ & $\begin{array}{c}\mathrm{IRSL} \text { at } 225^{\circ} \mathrm{C} \\
\text { for } 100 \mathrm{~s}\end{array}$ & $\begin{array}{c}\mathrm{SG} \mathrm{IRSL} \text { at } 225^{\circ} \mathrm{C} \\
\text { for } 5 \mathrm{~s}\end{array}$ \\
\hline & Test dose & Test dose & Test dose & Test dose & Test dose & Test dose \\
\hline & $\begin{array}{c}\text { Preheat at } 230^{\circ} \mathrm{C} \\
\text { for } 10 \mathrm{~s}\end{array}$ & $\begin{array}{c}\text { Preheat at } 230^{\circ} \mathrm{C} \\
\text { for } 10 \mathrm{~s}\end{array}$ & $\begin{array}{c}\text { Preheat at } 230^{\circ} \mathrm{C} \\
\text { for } 60 \mathrm{~s}\end{array}$ & $\begin{array}{c}\text { Preheat at } 230^{\circ} \mathrm{C} \\
\text { for } 60 \mathrm{~s}\end{array}$ & $\begin{array}{c}\text { Preheat at } 250^{\circ} \mathrm{C} \\
\text { for } 60 \mathrm{~s}\end{array}$ & $\begin{array}{c}\text { Preheat at } 230^{\circ} \mathrm{C} \\
\text { for } 60 \mathrm{~s}\end{array}$ \\
\hline & & & & & $\begin{array}{l}\mathrm{IRSL} \text { at } 50^{\circ} \mathrm{C} \\
\text { for } 100 \mathrm{~s}\end{array}$ & $\begin{array}{l}\mathrm{IRSL} \text { at } 50^{\circ} \mathrm{C} \\
\text { for } 100 \mathrm{~s}\end{array}$ \\
\hline $\mathrm{Tn} / \mathrm{Tx}$ & $\begin{array}{l}\text { OSL at } 125^{\circ} \mathrm{C} \\
\text { for } 100 \mathrm{~s}\end{array}$ & $\begin{array}{c}\text { SG OSL at } 125^{\circ} \mathrm{C} \\
\text { for } 5 \mathrm{~s}\end{array}$ & $\begin{array}{l}\text { IRSL at } 50^{\circ} \mathrm{C} \\
\text { for } 300 \mathrm{~s}\end{array}$ & $\begin{array}{l}\text { SG IRSL at } 50^{\circ} \mathrm{C} \\
\text { for } 5 \mathrm{~s}\end{array}$ & $\begin{array}{l}\mathrm{IRSL} \text { at } 225^{\circ} \mathrm{C} \\
\text { for } 100 \mathrm{~s}\end{array}$ & $\begin{array}{c}\text { SG IRSL at } 225^{\circ} \mathrm{C} \\
\text { for } 5 \mathrm{~s}\end{array}$ \\
\hline
\end{tabular}


$\left(D_{\mathrm{e}}\right)$ values from individual aliquots were used to calculate the palaeodose and uncertainty. Preheat temperature was estimated on the basis of performance tests according to Wintle and Murray (2006). Preheat tests are commonly used to assess appropriate preheat temperatures based on a plateau. However, on samples which are potentially partially bleached due to their sedimentary history, there may be no preheat plateau observable due to strongly varying $D_{\mathrm{e}}$ values. Therefore dose recovery tests at different preheat temperatures with given doses of $c a .100 \mathrm{~Gy}$ were performed in order to obtain a suitable preheat temperature. Bleaching of the samples for these tests was done in the readers using a normal luminescence readout (i.e. $60 \mathrm{~s}$ blue shine for quartz at $125^{\circ} \mathrm{C}$ and $300 \mathrm{~s}$ IR shine at $50^{\circ} \mathrm{C}$ for feldspar). The appropriate preheat temperature was chosen where dose recovery was within $10 \%$ of unity and sensitivity change during the SAR protocol was low. Preheat temperatures of $230^{\circ} \mathrm{C}$ were chosen both for quartz and feldspar. Equivalent doses were calculated using Luminescence Analyst 4.11 (Duller, 2013).

Dose response curves were fitted using a single saturating exponential function for both quartz and feldspar. In Fig. 3 we present two dose response curves for a high dose ( $c a .100 \mathrm{~Gy}$ ) of a $2 \mathrm{~mm}$ quartz aliquot and a $1 \mathrm{~mm}$ feldspar aliquot showing a dose similar to the resulting palaeodoses. A measurement error of $1.5 \%$ was included in the $D_{\mathrm{e}}$ determination for single aliquot measurements and $2.4 \%$ for single grains according to Trauerstein et al. (2012); the error on curve fitting is included.

\section{Measurements on quartz}

Stimulation was done using blue LEDs $(\lambda=470 \mathrm{~nm})$ delivering $c a .35 \mathrm{~mW} \mathrm{~cm}^{-2}$ at sample position. The signal was detected through a $7.5 \mathrm{~mm}$ Hoya U-340 transmission filter which blocks wavelengths above $390 \mathrm{~nm}$ with a peak transmission at $340 \mathrm{~nm}$. Single grain quartz measurements were performed using a $\mathrm{Nd}: \mathrm{YVO}_{4}$ solid state diode-pumped laser emitting at $532 \mathrm{~nm}$ with signal detection through a $2.5 \mathrm{~mm}$ Hoya U-340 filter. Decay curves for quartz OSL are shown in Figs. 4a and 4d.

Continuous wave $(\mathrm{CW})$ decay curves of quartz can be fitted to several components (Smith and Rhodes, 1994). Each of the components has the form

$L(t)=n_{0} b \exp (-b t)$

(McKeever and Chen, 1997, p. 653) where, $L$ is the luminescence intensity at time $t, n_{0}$ is the initial concentration of trapped electrons and $b$ is the detrapping probability. The components are commonly referred to as fast, medium and slow components. For OSL dating the fast component is usually used, although the medium component cannot be completely isolated from this. Problems arise when the medium component is unstable and its influence on the fast component varies strongly as observed by Steffen et al. (2009). A short integral is therefore preferred for quartz, in order to minimise the contribution of a possibly unstable medium component on the fast component. Deconvolution was carried out on several decay curves from aliquots of both samples in order to confirm that the fast component dominates the signal. An example of sample GE 2 is presented in Fig. 5, showing a dominance of the fast component during the integration interval. The relative contribution of the medium component to the total signal is almost identical for both the natural as well as the regenerated dose signal. Therefore we consider the medium component to be stable (cf. Steffen et al., 2009). This is supported by the fact that palaeodoses do not differ significantly from each other when using either $0.4 \mathrm{~s}$ or $1 \mathrm{~s}$ signal integration intervals and applying a late background subtraction. Applying approaches to reduce the contribution of the medium component, such as an early background subtraction (Cunningham and Wallinga, 2010), are not necessary for our samples and only create poorer counting statistics for the
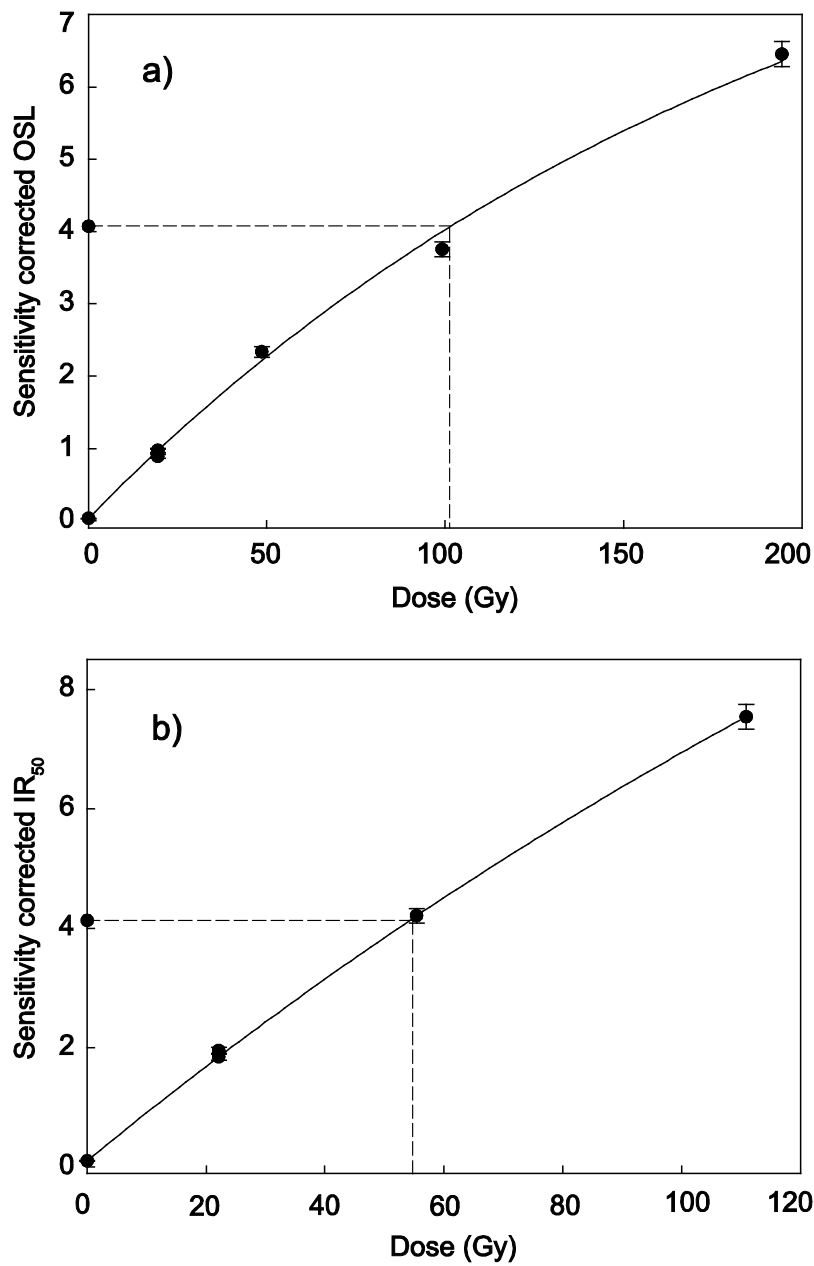

Fig. 3. Dose response curves for a) a relatively high dose (ca. $100 \mathrm{~Gy}$ ) of quartz OSL (Sample GE 3) and b) a dose which represents the expected age of feldspar IR50 (sample GE 2). Note near-linear relationship between sensitivity corrected IR50 and doses up to 110 Gy. Two higher dose points are not shown to improve readability of the area of interest. 

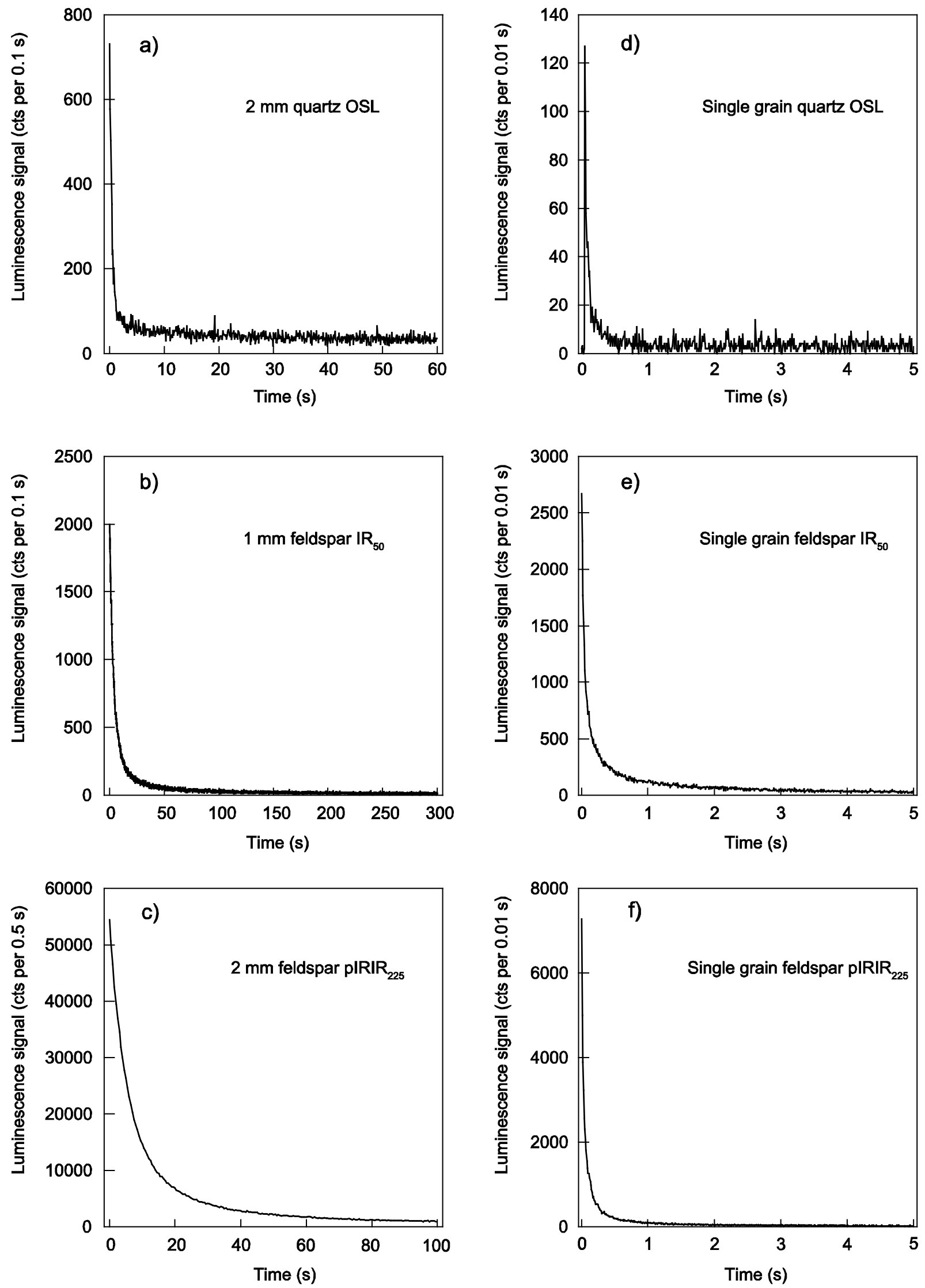

Fig. 4. Natural decay curves of selected aliquots from sample GE 3 (plots a to e) and GE 2 (plot f). 

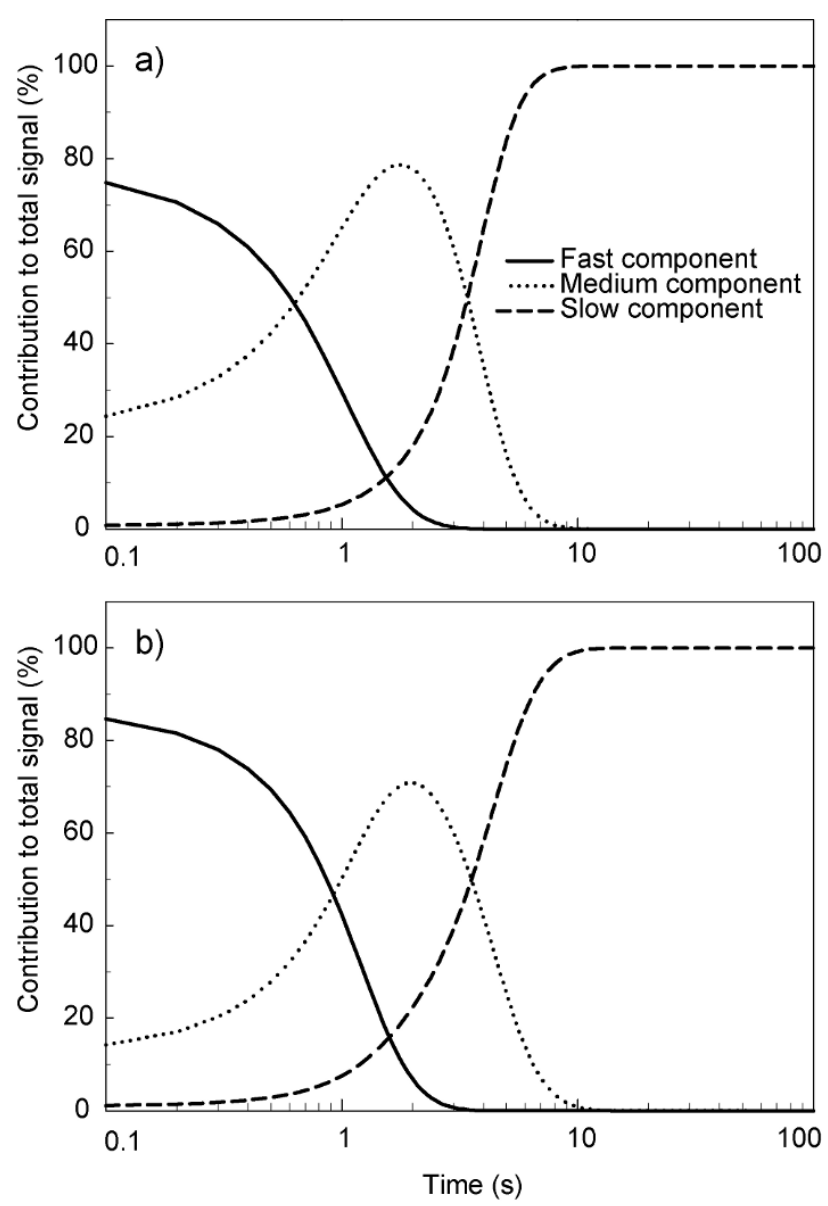

Fig. 5. Deconvolution of decay curves from sample GE 2 quartz (sample GE 3 displayed similar behaviour). a) natural decay curve, b) laboratory regenerated decay curve. A dominance of the fast component during the integration interval $(0.4 \mathrm{~s})$ and a stable medium component (only minor change between natural and laboratory regenerated dose) are shown.

relatively dim samples under consideration here. Hence, a conventional late background subtraction was used. For multi grain aliquots the first $0.4 \mathrm{~s}$, minus the signal between $40 \mathrm{~s}$ and $60 \mathrm{~s}$ for background estimation was used to calculate $D_{\mathrm{e}}$. The signal integral of the first $0.04 \mathrm{~s}$ minus the background estimate between $2 \mathrm{~s}$ and $5 \mathrm{~s}$ was used for single grains.

\section{Acceptance criteria for quartz}

Aliquots (multi grain and single grain) were rejected when the signal was less than three times the background, where test dose uncertainty was larger than $20 \%$, or when uncertainty of $D_{\mathrm{e}}$ was larger than $30 \%$. Murray and Wintle (2000) propose a recycling ratio rejection criterion within $10 \%$ from unity. However, for quartz with low sensitivity counting statistics may be poor, due to the low signal intensity. This is especially valid for low doses from small aliquots or single grains; hence the recycling ratio might not meet this criterion all the time. Rejecting these aliquots would bias the $D_{\mathrm{e}}$ distribution towards higher doses and decrease the size of the statistical basis (number of $D_{\mathrm{e}}$ ). Both effects are problematic when statistical models need to be applied. Applying the strict rejection criterion of $10 \%$ variability reduces our dataset for the $2 \mathrm{~mm}$ quartz aliquots to 23 out of 72 aliquots (GE 2), and 41 out of 67 aliquots (GE 3 ). The single grains are reduced to 52 out of $c a .4140$ (GE 2) and 43 out of $c a$. 1890 (GE 3). Allowing a recycling ratio within $20 \%$ of unity includes 34 out of $722 \mathrm{~mm}$ aliquots (GE 2) and 58 out of 67 (GE 3). The single grain distribution contains 111 out of 4140 for sample GE 2, whereas 76 grains of the $c a .1890$ measured grains of sample GE 3 pass. The mean dose does not change significantly using one or the other recycling ratio criterion: using the $10 \%$ criterion on $2 \mathrm{~mm}$ quartz aliquots of sample GE 2 results in mean dose of $69.3 \pm 6.5$ (CAM: $63.3 \pm 5.5$ ) whereas the $20 \%$ criterion yields a mean of $69.0 \pm 5.0$ (CAM: $63.7 \pm 4.3$ ). We therefore use a recycling ratio rejection criterion within $20 \%$ of unity for the quartz samples.

To minimise the contribution of a possible feldspar contamination to the quartz measurements we apply the OSL IR depletion ratio as proposed by Duller (2003) for both multi grain aliquots and single grains. For a comparison of quartz and feldspar, Duller (2003) reports a bimodal distribution of OSL IR depletion ratios where the feldspars are clearly separated (ratios lower than 0.4) from the quartz (ratios greater than 0.8). Based on this study we consider aliquots and single grains as being quartz-dominated when the OSL IR depletion ratio is above 0.8 .

Recuperation, expressed as the response to a zero dose compared to the natural dose, was generally low in our samples; on average, for quartz OSL recuperation was less than $5 \%$. $D_{\mathrm{e}}$ values that show more than $10 \%$ recuperation were rejected following arguments outlined in the section on feldspar measurements.

Saturation levels were monitored for all measurements and $D_{\mathrm{e}}$ values larger than $2 D_{0}$ were rejected as suggested by Wintle and Murray (2006). For our samples, only $20 D_{\mathrm{e}}$ values for single grains of sample GE 2 were rejected applying this criterion. We therefore consider the problem of biasing our distribution towards lower doses as minor. In addition we use age models which are not strongly dependent on values at the upper end of a distribution.

Altogether, $47-86 \%$ of the OSL measurements on multi grain aliquots pass the above discussed criteria, and only $3 \%$ of the quartz single grains.

\section{Measurements on feldspar}

For multiple grain feldspar aliquots stimulation was done using IR-LEDs $(\lambda=870 \mathrm{~nm})$ delivering $c a$. $115 \mathrm{~mW} \mathrm{~cm}{ }^{-2}$ at the sample position. Single grain feldspars were stimulated using an $830 \mathrm{~nm}$ IR-laser in the Risø single grain laser attachment. The signal was detected through a L.O.T.-Oriel D410/30 nm interference filter 
and one Schott BG-39 (effective detection wavelength of $410 \pm 30 \mathrm{~nm}$ ). Decay curves for IRSL are given in Figs. $4 \mathrm{~b}$ and $4 \mathrm{e}\left(\mathrm{IR}_{50}\right)$ and Figs. $4 \mathrm{c}$ and $\mathbf{4 f}\left(\mathrm{pIRIR}_{225}\right)$

There is controversy whether the $\mathrm{IR}_{50}$ signal consists of multiple components or not. While it was originally concluded that that the IRSL signal comprises only one component (Hütt et al., 1988; Trautmann et al., 2000), Tsukamoto et al. (2006) identified different components with different stabilities using time resolved luminescence. To investigate if the IRSL signal in our samples consists of different components, we calculated $D_{\mathrm{e}}$ with different integration intervals (Fig. 6) and found no dependency between $D_{\mathrm{e}}$ and the integration interval within the first $10 \mathrm{~s}$. Calculation of $D_{\mathrm{e}}$ for multi grain aliquots using $\mathrm{IR}_{50}$, utilises the first $10 \mathrm{~s}$, minus background estimation using the final $50 \mathrm{~s}$. For $\mathrm{IR}_{50}$ single grain measurements we use the first $1 \mathrm{~s}$, and use the final $2 \mathrm{~s}$ for background estimation.

\section{Acceptance criteria for feldspar}

Acceptance criteria for IRSL are the same as for OSL with the exception of the recycling ratio where feldspar samples are rejected when the recycling ratio is outside $10 \%$ of unity following Murray and Wintle (2000). Recuperation with the $\mathrm{IR}_{50}$ protocol is low (below $2 \%$ on average) for multiple grain aliquots, but higher for single grains $(7.3 \%$ on average for sample GE 3 and $5.0 \%$ for sample GE 2). Setting the threshold to $5 \%$ reduces the dataset of $\mathrm{IR}_{50}$ single grains for sample GE 3 to $24 D_{\mathrm{e}}$ values instead of 125 values when a threshold of $10 \%$ is applied. This supports the observation of Li et al. (2011), who found that a threshold of 5\% would not change the resulting dose of the distribution compared to a $10 \%$ threshold, but strongly decreases the number of values in the distribution. We therefore only reject aliquots that show recuperation larger than $10 \%$. Some $D_{\mathrm{e}}$ values of

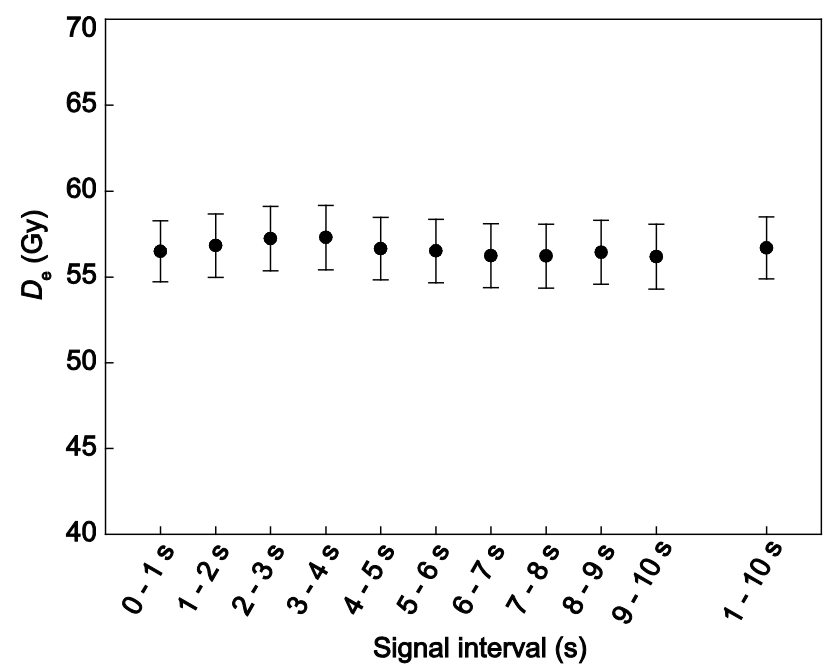

Fig. 6. Plateau plots on feldspar IR50 showing independence of integration interval and resulting $D_{e}$ (sample $G E 3,6 \mathrm{~mm}$ aliquots) sample GE 2 had to be rejected as they were above the saturation level $(8 \%$ of the small aliquots, $3 \%$ of the single grains). In total, more than $70 \%$ of the multi grain aliquots measured with $\mathrm{IR}_{50}$ pass these criteria; for the $\mathrm{IR}_{50}$ single grains it is about $17 \%$.

\section{Fading of I $R_{50}$ signal}

Fading tests on multi grain aliquots were carried out on the feldspar fraction of both samples in order to detect anomalous fading. The fading tests were based on delayed $L_{x} / T_{x}$ measurements, with the preheat directly following irradiation and different storage times before $L_{x}$ measurements (Auclair et al., 2003). Delay of the measurements was up to 10 hours after irradiation. The $\mathrm{L}_{\mathrm{x}} / \mathrm{T}_{\mathrm{x}}$ ratios measured after different delays are plotted against the time delay between irradiation and $\mathrm{IR}_{50}$ measurement on a log scale, the calculated percentage of signal loss per decade is referred to as the g-value (Aitken, 1985).

The fading test on three multiple grain aliquots of sample GE 3 results in a mean g-value of $2.5 \pm 0.1 \%$ per decade (Fig. 7). The same test on Sample GE 2 yields a mean of $2.6 \pm 0.3 \%$ per decade. These g-values are used for fading correction using the R-package 'Luminescence' (Kreutzer et al., 2012) which corrects according to Huntley and Lamothe (2001). This correction is restricted to $D_{\mathrm{e}}$ values fitting to the linear part of the dose response curve. Our samples have palaeodoses that lie in the (quasi) linear part of the dose response curve (cf. Fig. 3b). The fading rates assessed are moderate and in the same range as samples from other sites in the region presented by Lowick et al. (2012). The uncorrected and corrected ages are presented in Table 2.

\section{pIRIR 225}

The pIRIR measurements on multi grain aliquots were done using the same pIRIR 225 protocol used by Lowick et

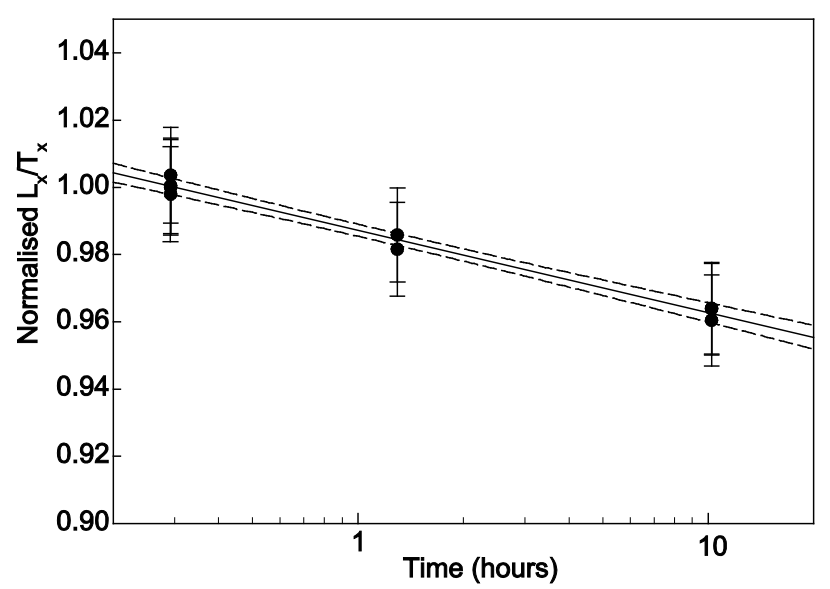

Fig. 7. Example of a fading test on feldspar from sample GE 3, for which a mean g-value of $2.5 \% \pm 0.1 \%$ was assessed (based on 3 aliquots). Solid line: regression through data, dashed lines: $95 \%$ confidence intervals. 
Table 2. Palaeodoses and ages of different aliquot sizes and different age models. SG: single grains. $n_{\text {tot: }}$ total number of aliquots or grains (SG) analysed (grain number assumed on $90 \%$ filling of $S G$ discs). $n$ : number of $D_{e}$ used for palaeodose calculation. OD: overdispersion of $D_{e}$ distribution. $\sigma_{b}$ : value used in the MAM. CAM: central age model. MAM: minimum age model. n/a.: not applicable to $6 \mathrm{~mm}$ aliquots due to averaging effect on large aliquots (see discussion in text). " $p I R I R_{225}$ : a mean residual has been subtracted from each $D_{\mathrm{e}}$.

\begin{tabular}{|c|c|c|c|c|c|c|c|c|c|c|c|c|c|}
\hline \multirow[t]{2}{*}{ Sample } & \multirow{2}{*}{ Mineral } & \multirow[t]{2}{*}{ Protocol } & \multirow[t]{2}{*}{ Aliquot size } & \multirow[t]{2}{*}{$\mathrm{n}_{\text {tot }}$} & \multirow[t]{2}{*}{$\mathbf{n}$} & \multirow[t]{2}{*}{ OD } & \multirow[t]{2}{*}{$\sigma_{b}$} & \multicolumn{2}{|c|}{ Palaeodose (Gy) } & \multicolumn{2}{|c|}{ Age (ka) } & \multicolumn{2}{|c|}{$\begin{array}{c}\text { Age (ka) } \\
\text { fading corrected }\end{array}$} \\
\hline & & & & & & & & CAM & MAM & CAM & MAM & CAM & MAM \\
\hline GE 2 & $\mathrm{~F}$ & IR50 & $6 \mathrm{~mm}$ & 12 & 12 & 0.22 & $\mathrm{n} / \mathrm{a}$ & $228.0 \pm 14.7$ & $\mathrm{n} / \mathrm{a}$ & $107.8 \pm 9.7$ & $\mathrm{n} / \mathrm{a}$ & $141.8 \pm 13.3$ & $\mathrm{n} / \mathrm{a}$ \\
\hline GE 2 & $\mathrm{~F}$ & IR50 & $1 \mathrm{~mm}$ & 61 & 36 & 0.71 & 0.18 & $119.0 \pm 14.0$ & $49.4 \pm 7.2$ & $56.2 \pm 7.5$ & $23.4 \pm 3.7$ & $73.2 \pm 9.8$ & $30.0 \pm 4.6$ \\
\hline GE 2 & $\mathrm{~F}$ & pIRIR225 & $1 \mathrm{~mm}$ & 48 & 26 & 0.58 & 0.18 & $204.2 \pm 23.6$ & $85.7 \pm 13.9$ & $96.5 \pm 12.7$ & $40.5 \pm 7.1$ & - & - \\
\hline GE 2 & $\mathrm{~F}$ & ${ }^{*}$ pIRIR225 & $1 \mathrm{~mm}$ & 48 & 26 & 0.63 & 0.18 & $186.4 \pm 25.2$ & $69.1 \pm 12.0$ & $88.1 \pm 12.5$ & $34.6 \pm 6.0$ & - & - \\
\hline GE 2 & $\mathrm{~F}$ & IR50 & SG & 720 & 139 & 0.77 & 0.28 & $129.1 \pm 8.57$ & $45.1 \pm 5.3$ & $61.0 \pm 5.61$ & $21.3 \pm 2.9$ & $79.2 \pm 8.8$ & $27.3 \pm 5.2$ \\
\hline GE 2 & $\mathrm{~F}$ & pIRIR225 & SG & 810 & 136 & 0.68 & 0.28 & $108.6 \pm 6.4$ & $50.0 \pm 6.4$ & $51.3 \pm 4.5$ & $23.6 \pm 3.4$ & - & - \\
\hline GE 2 & $\mathrm{~F}$ & ${ }^{*} p \mid R I R 225$ & $S G$ & 810 & 136 & 0.81 & 0.28 & $90.1 \pm 6.3$ & $31.5 \pm 3.9$ & $42.6 \pm 4.0$ & $14.9 \pm 2.1$ & - & - \\
\hline GE 2 & $Q$ & OSL & $6 \mathrm{~mm}$ & 7 & 6 & 0.23 & $\mathrm{n} / \mathrm{a}$ & $57.3 \pm 5.4$ & n/a & $44.4 \pm 4.8$ & $\mathrm{n} / \mathrm{a}$ & - & - \\
\hline GE 2 & $Q$ & OSL & $2 \mathrm{~mm}$ & 72 & 34 & 0.39 & 0.19 & $63.7 \pm 4.3$ & $42.5 \pm 5.5$ & $49.4 \pm 4.3$ & $32.9 \pm 4.6$ & - & - \\
\hline GE 2 & $Q$ & OSL & SG & 4140 & 111 & 0.63 & 0.32 & $66.8 \pm 4.1$ & $35.2 \pm 4.9$ & $51.8 \pm 4.3$ & $27.3 \pm 4.1$ & - & - \\
\hline GE 3 & $F$ & IR50 & $6 \mathrm{~mm}$ & 12 & 12 & 0.12 & $\mathrm{n} / \mathrm{a}$ & $54.6 \pm 1.9$ & n/a & $25.0 \pm 1.9$ & n/a & $31.7 \pm 2.4$ & $\mathrm{n} / \mathrm{a}$ \\
\hline GE 3 & $\mathrm{~F}$ & pIRIR225 & $2 \mathrm{~mm}$ & 12 & 12 & 0.13 & 0.18 & $61.4 \pm 2.3$ & $60.0 \pm 5.1$ & $28.3 \pm 2.1$ & $27.5 \pm 3.0$ & - & - \\
\hline GE 3 & $F$ & ${ }^{*}$ pIRIR225 & $2 \mathrm{~mm}$ & 12 & 12 & 0.15 & 0.18 & $53.2 \pm 2.3$ & $51.5 \pm 4.8$ & $24.4 \pm 1.9$ & $23.6 \pm 2.7$ & - & - \\
\hline GE 3 & $\mathrm{~F}$ & IR50 & $1 \mathrm{~mm}$ & 52 & 48 & 0.25 & 0.18 & $50.9 \pm 1.8$ & $44.9 \pm 6.1$ & $23.4 \pm 1.7$ & $20.6 \pm 3.1$ & $29.6 \pm 2.3$ & $26.1 \pm 3.9$ \\
\hline GE 3 & $\mathrm{~F}$ & IR50 & SG & 720 & 125 & 0.44 & 0.28 & $59.4 \pm 2.4$ & $47.7 \pm 10.7$ & $27.2 \pm 2.1$ & $21.9 \pm 5.1$ & $34.5 \pm 2.8$ & $27.7 \pm 6.8$ \\
\hline GE 3 & $Q$ & OSL & $6 \mathrm{~mm}$ & 12 & 9 & 0.17 & $\mathrm{n} / \mathrm{a}$ & $41.7 \pm 2.4$ & $\mathrm{n} / \mathrm{a}$ & $30.6 \pm 2.5$ & n/a & - & - \\
\hline GE 3 & $Q$ & OSL & $2 \mathrm{~mm}$ & 67 & 58 & 0.23 & 0.19 & $39.6 \pm 1.2$ & $35.5 \pm 4.2$ & $29.1 \pm 1.9$ & $26.1 \pm 3.4$ & - & - \\
\hline GE 3 & $Q$ & OSL & SG & 1890 & 76 & 0.35 & 0.32 & $44.1 \pm 2.0$ & $39.3 \pm 5.9$ & $32.4 \pm 2.4$ & $28.9 \pm 4.7$ & - & - \\
\hline
\end{tabular}

al. (2012). Single grain pIRIR 225 was performed using a modified version of the protocol of Reimann et al. (2012). Details for both protocols are shown in Table 1. $D_{\mathrm{e}}$ calculation is based on the first $2 \mathrm{~s}$ of the decay curve, and using the last $20 \mathrm{~s}$ for background estimation for the multiple grain aliquots, and on the first second minus the last $2 \mathrm{~s}$ for the single grains. Acceptance criteria are the same as for the $\mathrm{IR}_{50}$ measurements mentioned above. Recuperation with the pIRIR 225 protocol is on average below $4 \%$ for the selected aliquots. $3 \%$ of the single grains and one multigrain aliquot measured with the $\mathrm{pIRIR}_{225}$ protocol were rejected for being in saturation. About $17 \%$ of the measured single grains pass the rejection criteria. For multi grain aliquots the acceptance ratio varies between 54\% (sample GE 2), and 100\% (sample GE 3).

Residuals and dose recovery tests (given dose of $c a$. $100 \mathrm{~Gy}$ ) were measured after bleaching aliquots for up to $30 \mathrm{~h}$ under incandescent light with a daylight spectrum (Sunlux Ambiance bulb); additional light sources, which may have contributed to bleaching were conventional indoor fluorescent illumination and window-filtered sunlight.

\section{External dose rate determination}

The concentration of dose-rate relevant elements $(\mathrm{U}$, $\mathrm{K}$, Th) was determined using high-resolution $\gamma$ spectrometry on bulk sediment samples of $c a .450 \mathrm{~g}$ (cf. Preusser and Kasper, 2001); results and resulting dose rates are shown in Table 3. No indication for radioactive disequilibria in the Uranium decay chain is observed, when comparing the activity of ${ }^{238} \mathrm{U}$ and ${ }^{226} \mathrm{Ra}$ (cf. Preusser and Degering, 2007). The dose-rate is calculated using ADELE software (Kulig, 2005), which follows Prescott and Hutton (1994) for the cosmic dose rate and uses the conversion factors of Adamiec and Aitken (1998). A sediment overburden of $6 \mathrm{~m}$ (sample GE 2) and $9 \mathrm{~m}$ (sample GE 3) with a density of $2 \mathrm{~g} \mathrm{~cm}^{-3}$ is assumed during burial, representing the present day depth situation. The calculated contribution from cosmic radiation is $83 \mathrm{mGy} \mathrm{ka}^{-1}$ (GE 2) and $104 \mathrm{mGy} \mathrm{ka}^{-1}$ (GE 3), respectively. The values for cosmic contribution are taken into account with a relative uncertainty of $10 \%$.

The efficiency of alpha particles in causing radiation damage (alpha efficiency, a-value) is assumed based on

Table 3. Results of high-resolution y-spectrometry and resulting dose rates during burial. (Q: quartz, F: feldspar).

\begin{tabular}{ccccccc}
\hline Sample & $\begin{array}{c}\mathrm{K} \\
(\%)\end{array}$ & $\begin{array}{c}\text { Th } \\
(\mathrm{ppm})\end{array}$ & $\begin{array}{c}\mathrm{U} \\
(\mathbf{p p m})\end{array}$ & $\begin{array}{c}\text { Cosmic dose rate } \\
\left(\mathrm{mGy} \mathrm{ka}^{-1}\right)\end{array}$ & $\begin{array}{c}\text { Total dose rate to Q } \\
\left(\mathrm{Gy} \mathrm{ka}^{-1}\right)\end{array}$ & $\begin{array}{c}\text { Total dose rate to } \mathrm{F} \\
(\mathrm{Gy} \mathrm{ka})\end{array}$ \\
\hline GE2 & $0.84 \pm 0.02$ & $3.42 \pm 0.09$ & $1.53 \pm 0.03$ & 83 & $1.29 \pm 0.07$ & $2.12 \pm 0.13$ \\
GE3 & $0.88 \pm 0.02$ & $3.52 \pm 0.16$ & $1.51 \pm 0.04$ & 104 & $1.36 \pm 0.08$ & $2.18 \pm 0.14$ \\
\hline
\end{tabular}


literature values of the geographically closest assessments. For the feldspar an a-value of $0.05 \pm 0.01$ was applied (Preusser, 1999b; Preusser et al., 2001). Since the affected rim is removed by HF-etching of coarse grain quartz, the a-value is not relevant for palaeodose estimates on this mineral.

Field water content is assessed by drying the sample at $50^{\circ} \mathrm{C}$. A water content of $12 \%$ (of dry mass) for both samples was measured. To account for possible change in sediment moisture in the past, a value of $12 \pm 4 \%$ is used to correct for the attenuation of radiation by water.

\section{Internal dose rate of feldspar}

To assess the internal dose rate for feldspars an accurate estimate of the potassium content is crucial since the unstable ${ }^{40} \mathrm{~K}$ isotope ( $\beta^{+}$and $\beta^{-}$decay) is the main source of internal radiation within feldspar grains. In general, a content of $12.5 \pm 0.5 \mathrm{wt} . \% \mathrm{~K}$ following the recommendation of Huntley and Baril (1997) is often assumed. Lamothe et al. (1994) measured potassium contents in single feldspar grains using a microprobe, and obtained a mean of $11.66 \mathrm{wt} \% \mathrm{~K}$. Measurements on a coastal dune sample from the North Island of New Zealand using laser ablation inductively coupled plasma mass spectrometry (LA-ICP-MS) by Smedley et al. (2012) shows lower values (assumed to originate from perthitic exsolution structures) and these authors suggest a potassium content of $10 \pm 2 \mathrm{wt} . \%$ as an appropriate value for dating.

We used electron microprobe analysis (EMPA) to assess K-contents on single grains of sample GE 3 that had previously been measured for their luminescence to enable a comparison of $\mathrm{IR}_{50}$ signal and $\mathrm{K}$-content. After the luminescence measurements were performed, the grains were fixed within the single grain discs by dropping liquid, quick hardening cyanoacrylate onto the discs. Later the discs were embedded in acryl, ground down in order to access the interior of the grains, and the surface was polished. To avoid charging during measuring the polished surface of the discs was carbon coated.

The EMPA were carried out on a JEOL 8200 SUPERPROBE. Reproducibility was tested by repeated measurements within homogeneous phases on different grains. The average on the standard deviations of those measurements yielded a reproducibility of $0.13 \%$ for $\mathrm{K}$. Calibration was tested on a K-rich feldspar $\left(\left[\mathrm{K}_{0.65} \mathrm{Al}_{0.32}\right] \mathrm{Si}_{3} \mathrm{O}_{8}\right)$ standard with 9.272 wt.\% K. Repeated measurements on the standard yielded $9.44 \mathrm{wt} \% \mathrm{~K}$ and we therefore deduce a relative uncertainty of $2 \%$ on these measurements.

\section{RESULTS}

\section{Internal dose rate of feldspar}

Scanning electron microscopy is able to display different chemical phases based on backscattered electrons (BSE). Visual inspection of the grains using the BSE pictures before the EMPA measurements revealed no evidence for perthitic exsolution lamellae. Multiple measurements on grains showing different phases did not reveal different potassium contents of the phases. Hence, our measurements, despite being measured on small portions of the grains, reflect the chemical composition of the entire grain. For a total of 52 different grains, both luminescence and chemical composition were measured. Of these 52, only three grains were quartz and one grain was Na-feldspar (albite). Four further feldspar grains had an intermediate composition between the $\mathrm{Na}$ - and $\mathrm{K}$-end members with less than $10 \mathrm{wt} . \% \mathrm{~K}$. The remaining 44 grains were of a composition higher than $10 \mathrm{wt} . \% \mathrm{~K}$. This confirms that the density separation process is effective in isolating K-rich feldspar. For luminescence dating it is important which feldspars give a signal that passes the rejection criteria. For 27 of the original 52 grains, a $D_{\mathrm{e}}$ could be calculated in dose recovery tests. The albite grain gave a very weak signal in the given detection window and did not pass rejection criteria; two grains with intermediate composition passed, and these feldspars would therefore be included in the calculation of palaeodose. The average composition of all K-feldspars yielding a $D_{\mathrm{e}}$ is $12.9 \pm 0.4 \mathrm{wt} \% \% \mathrm{~K}$. As our analysis covers a rather small number of grains we do not use the measured value, but rely on the data of Huntley and Baril (1997), which are confirmed by our measurements but are statistically more robust. However, we use a value of $12.5 \pm 1.0$ wt.\% $\mathrm{K}$ to account for the $95 \%$ confidence interval as discussed by Huntley and Baril (1997).

\section{$D_{\mathrm{e}}$ distributions}

The two samples GE 2 and GE 3 are expected to be of very similar depositional age. Their total dose rates differ only by about $5 \%$ for quartz and less than $3 \%$ for feldspar (Table 3). Therefore the $D_{\mathrm{e}}$ values (and the resulting palaeodoses) can be directly compared. The two samples have distinctly different distributions as shown in Fig. 8. Only distributions of small multigrain aliquots and single grains measured with the OSL and $\mathrm{IR}_{50}$ protocol are compared. For the $6 \mathrm{~mm}$ aliquots and the pIRIR 225 protocol a smaller number of aliquots were measured and so the statistical requirements for a representative distribution are not fulfilled.

Sample GE 3 has relatively narrow, near Gaussian distributions for the approaches shown in Fig. 8. Together with the low overdispersion values (Table 2), this is interpreted to indicate complete bleaching of the luminescence signal prior to deposition. It can, therefore, be assumed that applying the CAM to these distributions will yield accurate burial doses. However, Fig. 8 reveals for each of the distributions of sample GE 3 (open symbols) a few $D_{\mathrm{e}}$ values with significantly higher doses, which could reflect incomplete resetting prior to deposition for these few aliquots.

Sample GE 2 (Fig. 8, closed symbols), in contrast, shows wide and positively skewed distributions in all 
a)

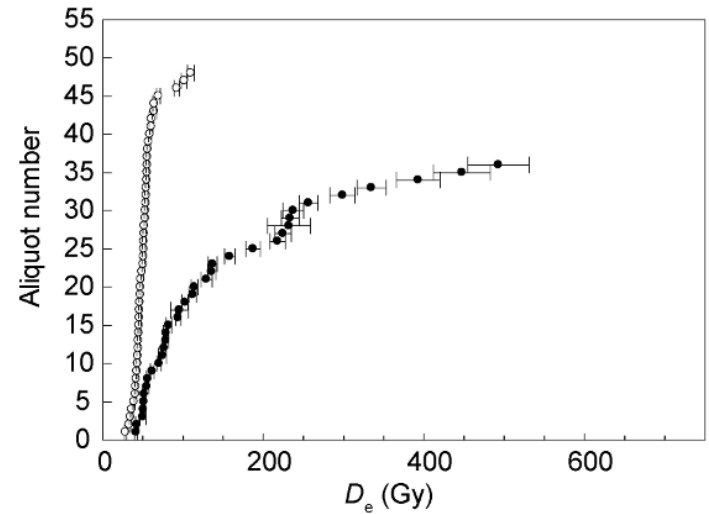

b)

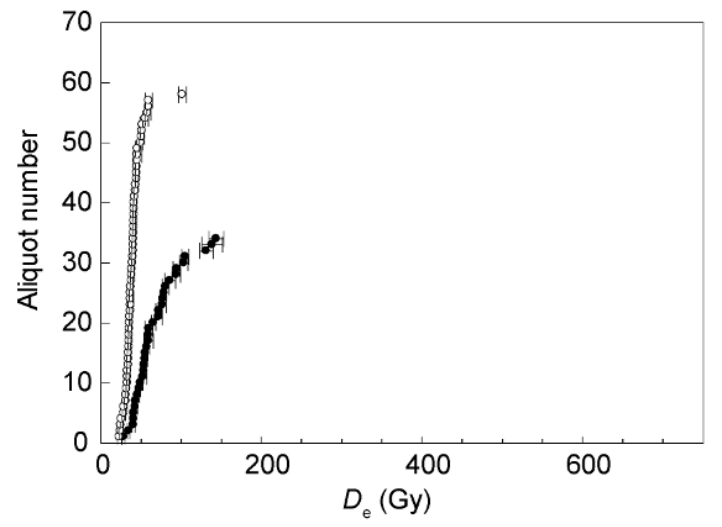

c)

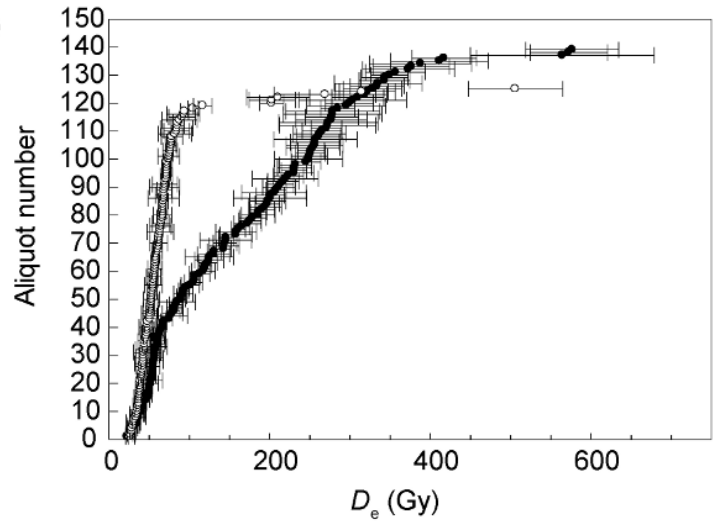

d)

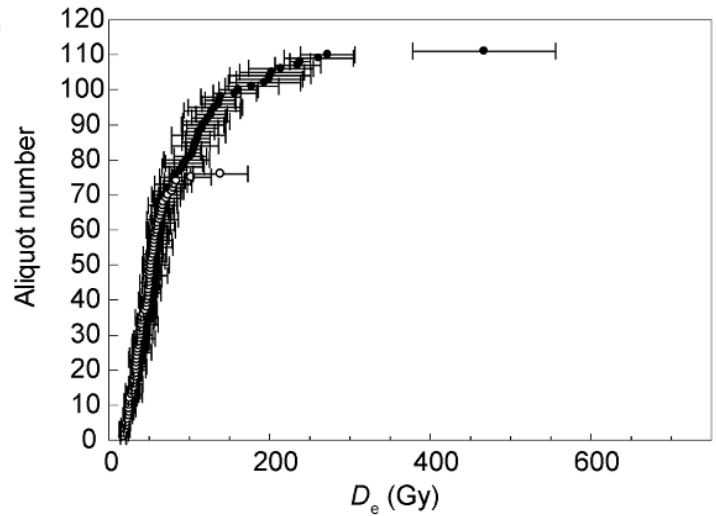

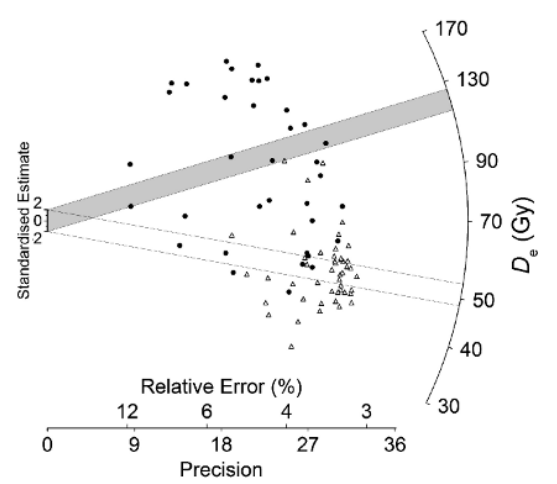
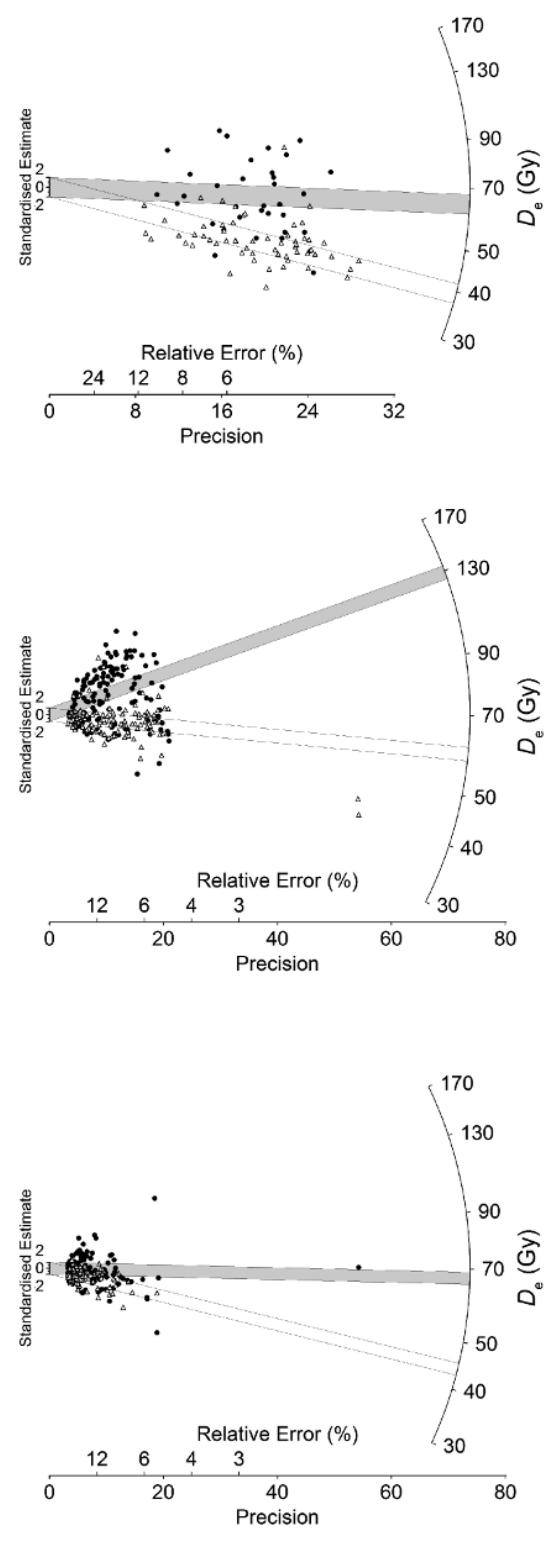

Fig. 8. $D_{e}$ distributions of selected measurement approaches. Left: cumulative distribution, right: corresponding radial plots; shaded area: CAM of sample GE 2, open area: CAM of sample GE 3. Closed symbols: sample GE 2, open symbols: sample GE 3. a) $1 \mathrm{~mm}$ feldspar IR5o, b) $2 \mathrm{~mm}$ quartz OSL, c) single grain feldspar IR50, d) single grain quartz OSL. 
approaches displayed. Differences in internal dosimetry in the feldspar are excluded as a cause for the spread in $D_{\mathrm{e}}$, as no correlation between potassium content and $D_{\mathrm{e}}$ was observed. High overdispersion values of 0.39 to 0.81 are calculated; this is interpreted to be due to partial bleaching. Support for this hypothesis comes from the test presented by Murray et al. (2012), which we apply here in a simplified way. For quartz of sample GE 3 we calculated a mean (CAM) palaeodose of $41.7 \pm 2.4$ Gy (6 $\mathrm{mm}$ aliquots). Due to the higher dose rate, a palaeodose of $69 \mathrm{~Gy}$ is expected for feldspar $\mathrm{IR}_{50}$, but this value has to be multiplied by 0.76 to correct for the observed fading. The fading corrected expected $\mathrm{IR}_{50}$ palaeodose of 52 Gy agrees very well with the measured value of $54.1 \pm 2.3$ Gy. This consistency indicates a well bleached sample. For sample GE 2 with a quartz palaeodose of $57.3 \pm 5.4 \mathrm{~Gy}$, an expected fading corrected $\mathrm{IR}_{50}$ palaeodose is $72 \mathrm{~Gy}$. Here, the measured $\mathrm{IR}_{50}$ dose of $220.8 \pm 13.4$ Gy far exceeds the expected dose, which strongly implies that partial bleaching is present in this sample. Nevertheless, the $D_{\mathrm{e}}$ distributions of GE 2 show a clustering of $D_{\mathrm{e}}$ values at the lower end of the distribution ('leading edge'; Lepper et al., 2000), in the same dose range as the distributions of sample GE 3 . This leads to the conclusion that a substantial number of grains were completely reset prior to deposition, while other grains were bleached to lesser degrees.

\section{Performance of the pIRIR 225 protocol}

Dose recovery tests on multiple grain aliquots of both samples using the $\mathrm{pIRIR}_{225}$ approach overestimate the given dose; GE 2 overestimates by $16 \%$, GE 3 by $42 \%$. Failing these tests recommends caution when interpreting the results of these measurements. However, Buylaert et al. (2012) observed no correlation between the performance of dose recovery tests and accuracy of the age when compared to independent age control. Interestingly, single grain measurements on sample GE 2 recovered the given dose within $4 \%$. Mean residuals of $8.5 \pm 1.2 \mathrm{~Gy}$ (GE 3 , single aliquots), $15.7 \pm 1.6$ Gy (GE 2, single aliquots) and $14.8 \pm 0.1$ Gy (GE 2, single grains) on the burial dose have been measured, and the subtraction of residuals from the palaeodose has been recommended (e.g. Thiel et al., 2011). In contrast, Sohbati et al. (2012) discuss this issue and decide not to subtract residuals for their alluvial samples from SE Spain as these were so low compared to the natural doses. For our samples, subtraction of mean residuals for multi-grain aliquot dose recovery tests still does not prevent them from overestimating, while such a subtraction would have resulted in the single grain dose recovery tests significantly underestimating the given dose.

\section{Minimum Age Model}

When applying the MAM of Galbraith et al. (1999) to extract the palaeodose of partially bleached sediments, the expected overdispersion, referred to as $\sigma_{b}$, has to be determined. The best way to obtain an appropriate $\sigma_{b}$ is to compare it to the overdispersion of a well bleached sample of a similar setting, ideally of the same source, mineral and age (Galbraith and Roberts, 2012), as it has been applied, for example, by Anderson et al. (2006). We are in the favourable situation of having an almost completely reset equivalent (sample GE 3 ) to the poorly bleached sample GE 2. To assess appropriate $\sigma_{b}$ values it has to be ensured that aliquots with partially bleached signals are not included in the overdispersion calculations. Therefore, we exclude some values at the upper end of the $D_{\mathrm{e}}$ distributions of sample GE 3 that are significantly larger than the rest of the distribution, assuming they represent incompletely reset signals. From the $1 \mathrm{~mm}$ aliquots measured with $\mathrm{IR}_{50}$, three values are excluded, and an overdispersion of $19 \%$ is calculated. The $2 \mathrm{~mm}$ OSL aliquot distribution has one outlier (Fig. 8b) and the remaining distribution has an overdispersion of $19 \%$. Removing the six highest $D_{\mathrm{e}}$ values from the $\mathrm{IR}_{50}$ single grains (Fig. 8c) results in an overdispersion of $27 \%$ and, excluding two values with a typically large uncertainties and large doses from the OSL single grains (Fig. 8d), yields a remaining overdispersion of $32 \%$.

The differences in overdispersion for small aliquots and single grains are in the same order as predicted by Cunningham et al. (2011). Applying the MAM to the $6 \mathrm{~mm}$ aliquots was not considered advisable as, for aliquots with 300 grains, completely bleached grains are masked by the luminescence from grains carrying a large inherited dose and so, only an average signal is measured (Olley et al., 1999; Wallinga, 2002b; Duller, 2008). To also test the MAM on pIRIR 225 data, $\sigma_{b}$ values assessed for the corresponding $\mathrm{IR}_{50}$ approaches are used. When applying the MAM we use the complete datasets, including all values we have identified as partially bleached.

\section{Age comparison}

Fig. 9 and Table 2 present the ages obtained by the different approaches. For the well-bleached sample GE3, for small aliquots we obtained a quartz OSL age of $29.1 \pm 1.9 \mathrm{ka}(2 \mathrm{~mm})$ and a fading corrected $\mathrm{IR}_{50}$ feldspar age $(1 \mathrm{~mm})$ of $29.6 \pm 2.3 \mathrm{ka}$ when using CAM. The MAM ages are $26.1 \pm 3.4 \mathrm{ka}(\mathrm{OSL})$ and $26.1 \pm 3.9 \mathrm{ka}$ (fading corrected $\left.\mathrm{IR}_{50}\right)$, respectively. The $6 \mathrm{~mm}$ aliquot ages are slightly (insignificantly) higher (OSL: $30.6 \pm 2.5 \mathrm{ka}$, fading corrected $\mathrm{IR}_{50} 31.7 \pm 2.4 \mathrm{ka}$ ). Quartz single grains yield ages of $32.4 \pm 2.4 \mathrm{ka}(\mathrm{CAM})$ and $28.9 \pm 4.7 \mathrm{ka}$ (MAM). Fading corrected ages of feldspar $\mathrm{IR}_{50}$ single grains of $34.5 \pm 2.8 \mathrm{ka}(\mathrm{CAM})$ and $27.7 \pm 6.8 \mathrm{ka}$ (MAM) are very similar to OSL single grains. pIRIR 225 ages from small aliquots (CAM: $28.3 \pm 2.1$ and MAM: $27.5 \pm 3.0 \mathrm{ka}$ ) are also in agreement with the OSL and $\mathrm{IR}_{50}$ ages and fit the expected age range. However, these ages are uncorrected and it should be remembered that the pIRIR 225 signal has been observed to fade, although usually less than the $\mathrm{IR}_{50}$ signal (Buylaert et al., 2009). 

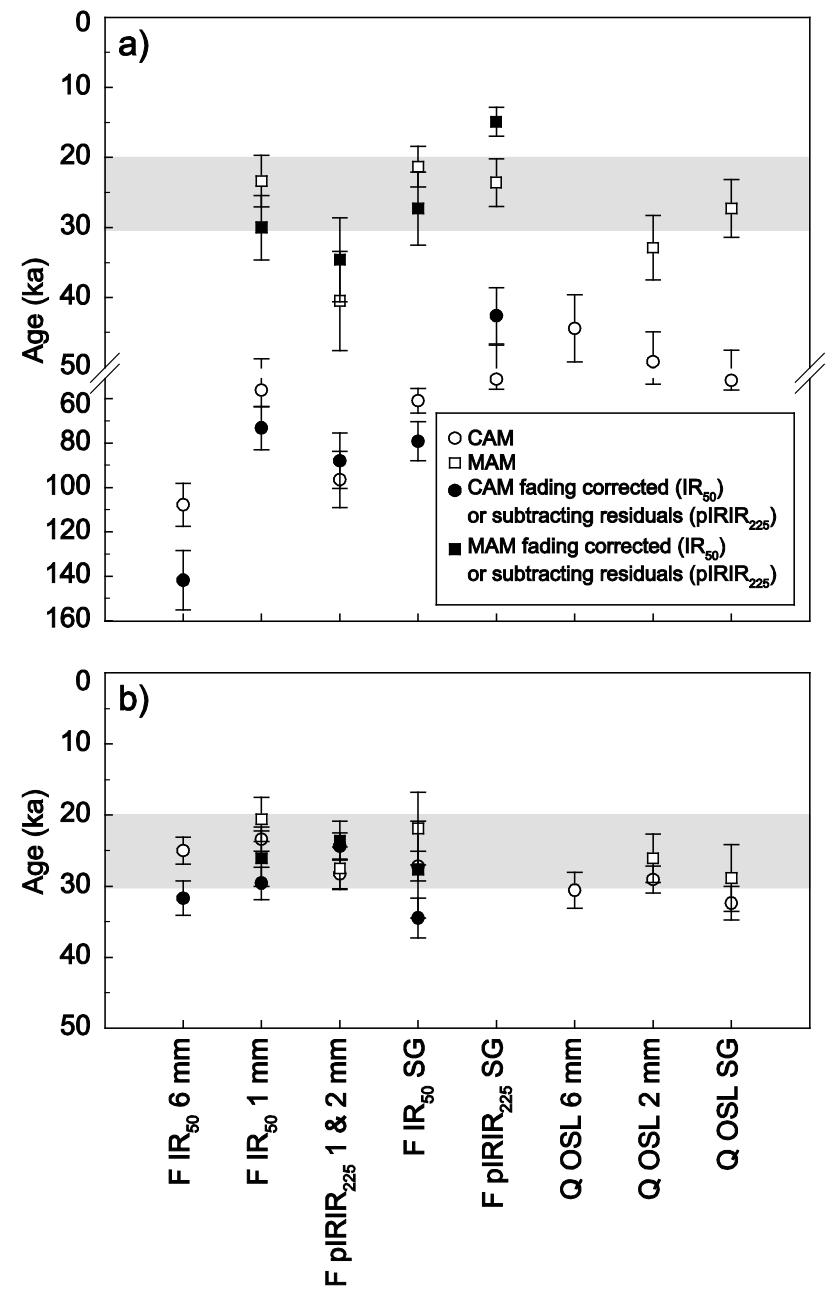

Fig. 9. Comparison of ages assessed by different approaches. a) sample GE 2, b) sample GE 3. Shaded area marks the expected age. Note break and change of scaling in the vertical axis in plot a).

It is noteworthy that MAM and CAM ages $\left(\mathrm{OSL}, \mathrm{IR}_{50}\right.$ and pIRIR $_{225}$ ) for this well bleached sample are consistent within uncertainties, with the central value of MAM ages being only slightly younger than CAM ages. This indicates that applying the MAM to a well bleached sample with an appropriate $\sigma_{b}$ value does not necessarily lead to inaccurate ages. This is in contrast to the observations of Murray et al. (2012), who found a significant underestimation of MAM ages compared to CAM ages on well bleached samples.

The ages for sample GE 2 differ significantly (Fig. 9a). A severe overestimation occurs with $6 \mathrm{~mm}$ aliquots where the fading corrected feldspar $\mathrm{IR}_{50}$ (CAM: $141.8 \pm 13.3 \mathrm{ka})$ predates the expected age of the sample (20-30 ka) by more than $100 \mathrm{ka}$ and gives an age beyond the Last Interglacial. It should be noted that the palaeodose corrected here is beyond the range for which the applied fading correction is designed. The uncorrected age, which is usually (in well bleached samples) expected to underestimate, yields $107.8 \pm 9.7 \mathrm{ka}$. The CAM $6 \mathrm{~mm}$ quartz OSL age of $44.4 \pm 4.8 \mathrm{ka}$ is also significantly overestimating. With small aliquots the CAM ages $\left(\mathrm{IR}_{50}\right.$ fading corrected: $73.2 \pm 9.8 \mathrm{ka}$, pIRIR $225: 51.3 \pm 4.5 \mathrm{ka}$, OSL: $49.4 \pm 4.3 \mathrm{ka})$ all significantly overestimate as well. The same observation is made for the CAM on single grains, where $\mathrm{IR}_{50}$ (fading corrected) yields $79.2 \pm 8.8 \mathrm{ka}$, pIRIR $_{225} 42.6 \pm 4.0 \mathrm{ka}$ and quartz OSL $51.8 \pm 4.3 \mathrm{ka}$. The observed age overestimations for sample GE 2 confirm the presence of partial bleaching, as already deduced from the large spread in the $D_{\mathrm{e}}$ distributions and the test for well bleached samples following Murray et al. (2012).This is confirmed by the application of the MAM to the small aliquots of quartz $(32.9 \pm 4.6 \mathrm{ka})$ and the fading corrected $\mathrm{IR}_{50}(30.0 \pm 4.6 \mathrm{ka})$, which do fit the expected age. However, the MAM pIRIR 225 age $(40.5 \pm 7.1 \mathrm{ka})$ clearly overestimates the expected age. All age overestimations for GE 2 are interpreted as due to partial bleaching and recommend the measurement of small aliquots as a minimum requirement, but preferably single grain analysis. Applying the MAM on feldspar $\mathrm{IR}_{50}$ single grains returns an age of $27.3 \pm 5.2 \mathrm{ka}$ (fading corrected), $27.3 \pm 4.1 \mathrm{ka}$ for quartz OSL, and $23.6 \pm 3.4 \mathrm{ka}$ for pIRIR 225 single grains. In contrast to Blomdin et al. (2012) (who used large aliquots for a test), we observe a bleached population in our pIRIR data when using single grains. However, the data are not fully comparable as Blomdin et al. (2012) used the pIRIR 290 protocol while here the $\mathrm{pIRIR}_{225}$ signal was used.

The MAM age obtained for the small aliquots of the well bleached sample GE 3 using the pIRIR 225 protocol agrees well with the age obtained from quartz OSL on small aliquots, when the residual dose is not subtracted. A subtraction of the residual is not necessarily indicated, as shown by the MAM pIRIR 225 single grain age of the partially bleached sample GE 2 . A clear underestimation $(14.9 \pm 2.1 \mathrm{ka})$ of the expected age range occurs when the residual is subtracted, but agreement within uncertainties with the other single grain data is reached when the residual is not subtracted. Only the pIRIR 225 age from small aliquots of sample GE 2 would be improved with regard to the expected age range when the residual is subtracted, but it appears likely that partial bleaching is the reason for the overestimation. The methodological difficulties call for caution with regard to the reliability of $\mathrm{pIRIR}_{225}$, despite the fact that they are consistent with age control.

\section{CONCLUSION}

We have shown data for two glaciofluvial samples from the same outcrop with only a few meters distance between the sampling spots and from the same sedimentological context. Despite this, the samples show clearly different levels of luminescence signal resetting, which require special attention when dating them. One sample is found to have a nearly complete resetting of the signal. This sample passes the test for well bleached quartz pre- 
sented by Murray et al. (2012), has low overdispersion values, and a non-skewed distribution. The other sample yields broad and skewed distributions, has much higher overdispersion values, and fails the test by Murray et al. (2012). It is therefore interpreted to be partially bleached prior to deposition. However, using small aliquots or single grains together with the MAM resulted in ages within the expected age range. As would be expected, using large aliquots led to inaccurate ages. Our results support the findings of Duller (2008) that single grains are preferred in environments where partial bleaching is likely. We have shown a significant age overestimation using the CAM for the partially bleached sample GE 2, and application of the MAM is a necessity. In both samples the $\mathrm{IR}_{50}$ ages are in better agreement with the quartz OSL ages when corrected for fading. Our findings imply that fading corrections are necessary, and produce accurate results, for the moderate fading rates observed in this study and palaedose values within the linear part of the dose response curve.

The advantage of feldspar single grain dating, at least for the samples investigated here, is that a large number of $D_{\mathrm{e}}$ values can be produced with relatively little effort, and therefore provides a more solid basis for the statistical analyses. This is due to the fact that a relatively large proportion of feldspar grains $(>17 \%)$ deliver suitable $\mathrm{IR}_{50}$ signals.

Despite methodological problems which call for caution, the applied pIRIR $_{225}$ protocol yields ages consistent with other approaches.

\section{ACKNOWLEDGEMENTS}

Samples were taken by Hans Rudolf Graf, Gächligen. Gamma spectrometric measurements were carried out by Sönke Szidat, Department of Chemistry and Biochemistry, University of Bern. Martin Robyr is thanked for advice and help with the EMPA. The authors would like to thank two anonymous reviewers for their thorough and detailed comments on an earlier version which helped to improve this article. Dorian Gaar is funded through Swiss National Science Foundation (SNF) projects 200021126784 and 200020 144456. Sally Lowick receives funding from the National Cooperative for the Disposal of Radioactive Waste (Nagra).

\section{REFERENCES}

Adamiec G and Aitken MJ, 1998. Dose-rate conversion factors: update. Ancient TL 16(2): 37-50.

Aitken MJ, 1985. Thermoluminescence dating. Academic Press, London, $359 \mathrm{p}$.

Alexanderson H and Murray AS, 2012. Problems and potential of OSL dating Weichselian and Holocene sediments in Sweden. Quaternary Science Reviews 44: 37-50, DOI 10.1016/j.quascirev.2009.09.020.

Anderson A, Roberts R, Dickinson W, Clark G, Burley D, de Biran A, Hope G and Nunn P, 2006. Times of sand: Sedimentary history and archaeology at the Sigatoka Dunes, Fiji. Geoarchaeology - an International Journal 21(2): 131-154, DOI 10.1002/Gea.20094.

Auclair M, Lamothe M and Huot S, 2003. Measurement of anomalous fading for feldspar IRSL using SAR. Radiation Measurements 37(4-5): 487-492, DOI 10.1016/S1350-4487(03)00018-0.

Bini A, Buoncristiani JF, Coutterand S, Ellwanger D, Felber M, Florineth D, Graf HR, Keller O, Kelly M, Schlüchter C and Schoeneich P, 2009. Die Schweiz während des letzteiszeitlichen Maximums (LGM) (Map 1:500 000). swisstopo, Wabern.

Blomdin R, Murray A, Thomsen KJ, Buylaert JP, Sohbati R, Jansson $\mathrm{KN}$ and Alexanderson H, 2012. Timing of the deglaciation in southern Patagonia: Testing the applicability of K-Feldspar IRSL. Quaternary Geochronology 10: 264-272, DOI 10.1016/j.quageo.2012.02.019.

Bronk Ramsey C, 2009. Bayesian Analysis of Radiocarbon Dates. Radiocarbon 51(1): 337-360.

Buylaert JP, Jain M, Murray AS, Thomsen KJ, Thiel C and Sohbati R, 2012. A robust feldspar luminescence dating method for Middle and Late Pleistocene sediments. Boreas 41(3): 435-451, DOI 10.1111/j.1502-3885.2012.00248.x.

Buylaert JP, Murray AS, Thomsen KJ and Jain M, 2009. Testing the potential of an elevated temperature IRSL signal from K-feldspar. Radiation Measurements 44(5-6): 560-565, DOI 10.1016/j.radmeas.2009.02.007.

Cunningham A, Wallinga $J$ and Minderhoud P, 2011. Expectations of scatter in equivalent-dose distributions when using multi-grain aliquots for OSL dating. Geochronometria 38(4): 424-431, DOI 10.2478/s13386-011-0048-z.

Cunningham AC and Wallinga J, 2010. Selection of integration time intervals for quartz OSL decay curves. Quaternary Geochronology 5(6): 657-666, DOI 10.1016/j.quageo.2010.08.004.

Duller GAT, 1994. Luminescence Dating of Poorly Bleached Sediments from Scotland. Quaternary Science Reviews 13(5-7): 521-524, DOI 10.1016/0277-3791(94)90070-1.

Duller GAT, 2003. Distinguishing quartz and feldspar in single grain luminescence measurements. Radiation Measurements 37(2): 161165, DOI 10.1016/S1350-4487(02)00170-1.

Duller GAT, 2008. Single-grain optical dating of Quaternary sediments: why aliquot size matters in luminescence dating. Boreas 37(4): 589-612, DOI 10.1111/j.1502-3885.2008.00051.x.

Duller GAT, 2013. Luminescence Analyst, 4.11 ed, Aberystwyth University.

Frechen M, Ellwanger D, Hinderer M, Lammermann-Barthel J, Neeb I and Techmer A, 2010. Late Pleistocene fluvial dynamics in the Hochrhein Valley and in the Upper Rhine Graben: chronological frame. International Journal of Earth Sciences 99(8): 1955-1974, DOI 10.1007/s00531-009-0482-9.

Frechen M, Ellwanger D, Hinderer M, Lammermann-Barthel J, Neeb I and Techmer A, 2012. Reply to Preusser et al. on Frechen et al. "Late Pleistocene fluvial dynamics in the Hochrhein Valley in the upper Rhine Graben: chronological frame". International Journal of Earth Sciences 101(1): 389-392, DOI 10.1007/s00531-0110638-2.

Fuchs M and Owen LA, 2008. Luminescence dating of glacial and associated sediments: review, recommendations and future directions. Boreas 37(4): 636-659, DOI 10.1111/j.15023885.2008.00052.x.

Fuller IC, Wintle AG and Duller GAT, 1994. Test of the Partial Bleach Methodology as Applied to the Infrared Stimulated Luminescence of an Alluvial Sediment from the Danube. Quaternary Science Reviews 13(5-7): 539-543, DOI 10.1016/0277-3791(94)90074-4.

Gaar D and Preusser F, 2012. Luminescence dating of mammoth remains from northern Switzerland. Quaternary Geochronology 10: 257-263, DOI 10.1016/j.quageo.2012.02.007.

Galbraith RF and Roberts RG, 2012. Statistical aspects of equivalent dose and error calculation and display in OSL dating: An overview and some recommendations. Quaternary Geochronology 11: 1-27, DOI 10.1016/j.quageo.2012.04.020.

Galbraith RF, Roberts RG, Laslett GM, Yoshida H and Olley JM, 1999. Optical dating of single and multiple grains of quartz from jinmium rock shelter, northern Australia, part 1, Experimental design 
and statistical models. Archaeometry 41: 339-364, DOI 10.1111/j.1475-4754.1999.tb00987.x.

Godfrey-Smith DI, Huntley DJ and Chen WH, 1988. Optical Dating Studies of Quartz and Feldspar Sediment Extracts. Quaternary Science Reviews 7(3-4): 373-380, DOI 10.1016/02773791(88)90032-7.

Graf HR, 2009. Stratigraphie von Mittel- und Spätpleistozän in der Nordschweiz (Stratigraphy of the Middle- and Late Pleistocene in Northern Switzerland). Landesgeologie, Wabern, 198 p (in German).

Hajdas I, 2009. Applications of Radiocarbon Dating Method. Radiocarbon 51(1): 79-90.

Hajdas I, Michczynski A, Bonani G, Wacker L and Furrer H, 2009. Dating Bones near the Limit of the Radiocarbon Dating Method: Study Case Mammoth from Niederweningen, ZH Switzerland. Radiocarbon 51(2): 675-680.

Huntley DJ and Baril MR, 1997. The K content of the K-feldspars beeing measured in optical dating or in thermoluminescence dating. Ancient TL 15(1): 11-14.

Huntley DJ and Lamothe M, 2001. Ubiquity of anomalous fading in Kfeldspars and the measurement and correction for it in optical dating. Canadian Journal of Earth Sciences 38(7): 1093-1106, DOI 10.1139/cjes-38-7-1093.

Hütt G, Jaek I and Tchonka J, 1988. Optical Dating - K-Feldspars Optical-Response Stimulation Spectra. Quaternary Science Reviews 7(3-4): 381-385, DOI 10.1016/0277-3791(88)90033-9.

Ivy-Ochs S, Kerschner H, Reuther A, Preusser F, Heine K, Maisch M, Kubik PW and Schlüchter C, 2008. Chronology of the last glacial cycle in the European Alps. Journal of Quaternary Science 23(67): 559-573, DOI 10.1002/Jqs. 1202.

Klasen N, Fiebig M, Preusser F and Radtke U, 2006. Luminescence properties of glaciofluvial sediments from the Bavarian Alpine Foreland. Radiation Measurements 41(7-8): 866-870, DOI 10.1016/j.radmeas.2006.04.014.

Klasen N, Fiebig M, Preusser F, Reitner JM and Radtke U, 2007. Luminescence dating of proglacial sediments from the Eastern Alps. Quaternary International 164-165: 21-32, DOI 10.1016/j.quaint.2006.12.003.

Kock S, Kramers JD, Preusser F and Wetzel A, 2009. Dating of Late Pleistocene terrace deposits of the River Rhine using Uranium series and luminescence methods: Potential and limitations. Quaternary Geochronology 4(5): 363-373, DOI 10.1016/j.quageo.2009.04.002.

Kreutzer S, Schmidt C, Fuchs MC, Dietze M, Fischer M and Fuchs M, 2012. Introducing an $\mathrm{R}$ package for luminescence dating analysis. Ancient TL 30(1): 1-8.

Kulig G, 2005. Erstellung einer Auswertesoftware zur Altersbestimmung mittels Lumineszenzverfahren unter spezieller Berücksichtigung des Einflusses radioaktiver Ungleichgewichte in der ${ }^{238}$ U-Zerfallsreihe (Creation of a software for luminescence dating with special attention to the influence of radioactive disequilibria in the ${ }^{238} \mathrm{U}$ decay chain). Technische Bergakademie Freiberg, Freiberg unpublished Bsc thesis (in German).

Lamothe M, Balescu S and Auclair M, 1994. Natural IRSL intensities and apparent luminescence ages of single feldspar grains extracted from partially bleached sediments. Radiation Measurements 23(23): 555-561, DOI 10.1016/1350-4487(94)90099-X.

Lapp T, Jain M, Thomsen KJ, Murray AS and Buylaert J-P, 2012. New luminescence measurement facilities in retrospective dosimetry. Radiation Measurements 47(9): 803-808, DOI 10.1016/j.radmeas.2012.02.006.

Lepper K, Larsen NA and McKeever SWS, 2000. Equivalent dose distribution analysis of Holocene eolian and fluvial quartz sands from Central Oklahoma. Radiation Measurements 32(5-6): 603608, DOI 10.1016/S1350-4487(00)00093-7.

Li B, Li SH, Duller GAT and Wintle AG, 2011. Infrared stimulated luminescence measurements of single grains of K-rich feldspar for isochron dating. Quaternary Geochronology 6(1): 71-81, DOI 10.1016/j.quageo.2010.02.003.
Lowick SE, Trauerstein M and Preusser F, 2012. Testing the application of post IR-IRSL dating to fine grain waterlain sediments. Quaternary Geochronology 8: 33-40, DOI 10.1016/j.quageo.2011.12.003.

McKeever SWS and Chen R, 1997. Luminescence models. Radiation Measurements 27(5-6): 625-661, DOI 10.1016/S13504487(97)00203-5.

Murray AS, Thomsen KJ, Masuda N, Buylaert JP and Jain M, 2012. Identifying well-bleached quartz using the different bleaching rates of quartz and feldspar luminescence signals. Radiation Measurements 47(9): 688-695, DOI 10.1016/j.radmeas.2012.05.006.

Murray AS and Wintle AG, 2000. Luminescence dating of quartz using an improved single-aliquot regenerative-dose protocol. Radiation Measurements 32(1): 57-73, DOI 10.1016/S1350-4487(99)00253$\mathrm{X}$.

Olley JM, Caitcheon GG and Roberts RG, 1999. The origin of dose distributions in fluvial sediments, and the prospect of dating single grains from fluvial deposits using optically stimulated luminescence. Radiation Measurements 30(2): 207-217, DOI 10.1016/S1350-4487(99)00040-2.

Prescott JR and Hutton JT, 1994. Cosmic ray contributions to dose rates for luminescence and ESR dating: Large depths and long-term time variations. Radiation Measurements 23(2-3): 497-500, DOI 10.1016/1350-4487(94)90086-8.

Preusser F, 1999a. Bleaching characteristics of some optically stimulated luminescence signals. Ancient TL 17(1): 11-14.

Preusser F, 1999b. Luminescence dating of fluvial sediments and overbank deposits from Gossau, Switzerland: fine grain dating. Quaternary Science Reviews 18(2): 217-222, DOI 10.1016/S02773791(98)00054-7.

Preusser F, Blei A, Graf H and Schlüchter C, 2007. Luminescence dating of Würmian (Weichselian) proglacial sediments from Switzerland: methodological aspects and stratigraphical conclusions. Boreas 36(2): 130-142, DOI 10.1080/03009480600923378.

Preusser F, Chithambo ML, Gotte T, Martini M, Ramseyer K, Sendezera EJ, Susino GJ and Wintle AG, 2009. Quartz as a natural luminescence dosimeter. Earth-Science Reviews 97(1-4): 184-214, DOI 10.1016/j.earscirev.2009.09.006.

Preusser F and Degering D, 2007. Luminescence dating of the Niederweningen mammoth site, Switzerland. Quaternary International 164-65: 106-112, DOI 10.1016/j.quaint.2006.12.002.

Preusser F, Degering D, Fuchs M, Hilgers A, Kadereit A, Klasen N, Krbetschek M, Richter D and Spencer JQG, 2008. Luminescence Dating: basics, methods and applications. E\&G-Quaternary Science Journal 57(1-2): 95-149, DOI 10.3285/eg.57.1-2.5.

Preusser F, Geyh MA and Schlüchter C, 2003. Timing of late pleistocene climate change in lowland Switzerland. Quaternary Science Reviews 22(14): 1435-1445, DOI 10.1016/S0277-3791(03)00127-

Preusser F, Graf HR, Keller O, Krayss E and Schlüchter C, 2011. Quaternary glaciation history of northern Switzerland. $E \& G-$ Quaternary Science Journal 60(2-3): 282-305, DOI 10.3285/eg.60.2-3.06.

Preusser F and Kasper HU, 2001. Comparison of dose rate determination using high-resolution gamma spectrometry and inductively coupled plasma-mass spectrometry. Ancient TL 19(1): 19-23.

Preusser F, Kock S and Rodnight H, 2012. Comment on Frechen et al. "Late Pleistocene fluvial dynamics in the Hochrhein Valle and in the Upper Rhine Graben: chronological frame". International Journal of Earth Sciences 101(1): 385-387, DOI 10.1007/s00531011-0641-7.

Preusser F, Müller BU and Schlüchter C, 2001. Luminescence dating of sediments from the Luthern Valley, central Switzerland, and implications for the chronology of the last glacial cycle. Quaternary Research 55(2): 215-222, DOI 10.1006/qres.2000.2208.

Preusser F, Ramseyer K and Schlüchter C, 2006. Characterisation of low OSL intensity quartz from the New Zealand Alps. Radiation

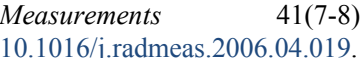

Qin JT and Zhou LP, 2012. Effects of thermally transferred signals in the post-IR IRSL SAR protocol. Radiation Measurements 47(9): 710-715, DOI 10.1016/j.radmeas.2011.12.011. 
Reimann T, Thomsen KJ, Jain M, Murray AS and Frechen M, 2012. Single-grain dating of young sediments using the pIRIR signal from feldspar. Quaternary Geochronology 11: 28-41, DOI 10.1016/j.quageo.2012.04.016.

Reimer PJ, Baillie MGL, Bard E, Bayliss A, Beck JW, Blackwell PG, Ramsey CB, Buck CE, Burr GS, Edwards RL, Friedrich M, Grootes PM, Guilderson TP, Hajdas I, Heaton TJ, Hogg AG, Hughen KA, Kaiser KF, Kromer B, McCormac FG, Manning SW, Reimer RW, Richards DA, Southon JR, Talamo S, Turney CSM, van der Plicht $\mathrm{J}$ and Weyhenmeye CE, 2009. Intcal09 and Marine09 Radiocarbon Age Calibration Curves, 0-50,000 Years Cal Bp. Radiocarbon 51(4): 1111-1150.

Rowan AV, Roberts HM, Jones MA, Duller GAT, Covey-Crump SJ and Brocklehurst SH, 2012. Optically stimulated luminescence dating of glaciofluvial sediments on the Canterbury Plains, South Island, New Zealand. Quaternary Geochronology 8: 10-22, DOI 10.1016/j.quageo.2011.11.013.

Schlüchter C, Maisch M, Suter J, Fitze P, Keller WA, Burga CA and Wynistorf E, 1987. Das Schieferkohlen-Profil von Gossau (Kanton Zürich) und seine stratigraphische Stellung innerhalb der letzten Eiszeit (The profile of foliated peat at Gossau (Kt. Zurich), and its stratigraphic position within the last glaciation). Vierteljahrsschrift der Naturforschenden Gesellschaft in Zürich 132(3): 135-174 (in German).

Smedley RK, Duller GAT, Pearce NJG and Roberts HM, 2012. Determining the K-content of single-grains of feldspar for luminescence dating. Radiation Measurements 47(9): 790-796, DOI 10.1016/j.radmeas.2012.01.014.

Smith BW and Rhodes EJ, 1994. Charge Movements in Quartz and Their Relevance to Optical Dating. Radiation Measurements 23(23): 329-333, DOI 10.1016/1350-4487(94)90060-4.

Sohbati R, Murray AS, Buylaert JP, Ortuno M, Cunha PP and Masana E, 2012. Luminescence dating of Pleistocene alluvial sediments affected by the Alhama de Murcia fault (eastern Betics, Spain) - a comparison between OSL, IRSL and post-IR IRSL ages. Boreas 41(2): 250-262, DOI 10.1111/j.1502-3885.2011.00230.x.

Spooner NA, 1994. The Anomalous Fading of Infrared-Stimulated Luminescence from Feldspars. Radiation Measurements 23(2-3): 625-632, DOI 10.1016/1350-4487(94)90111-2.

Steffen D, Preusser F and Schlunegger F, 2009. OSL quartz age underestimation due to unstable signal components. Quaternary Geochronology 4(5): 353-362, DOI 10.1016/j.quageo.2009.05.015.

Stevens T, Markovic SB, Zech M, Hambach U and Sumegi P, 2011. Dust deposition and climate in the Carpathian Basin over an inde pendently dated last glacial-interglacial cycle. Quaternary Science Reviews 30(5-6): 662-681, DOI 10.1016/j.quascirev.2010.12.011.

Thiel C, Buylaert J-P, Murray AS, Terhorst B, Tsukamoto S, Frechen M and Sprafke $T, 2011$. Investigating the chronostratigraphy of prominent palaeosols in Lower Austria using post-IR IRSL dating. E\&G - Quaternary Science Journal 60(1): 137-152, DOI 10.3285/eg.60.1.10.

Thomas PJ, Murray AS, Kjaer KH, Funder S and Larsen E, 2006. Optically Stimulated Luminescence (OSL) dating of glacial sediments from Arctic Russia - depositional bleaching and methodological aspects. Boreas 35(3): 587-599, DOI 10.1080/03009480600781933.

Thomsen KJ, Murray AS, Jain M and Botter-Jensen L, 2008. Laboratory fading rates of various luminescence signals from feldspar-rich sediment extracts. Radiation Measurements 43(9-10): 1474-1486, DOI 10.1016/j.radmeas.2008.06.002.

Thrasher IM, Mauz B, Chiverrell RC and Lang A, 2009. Luminescence dating of glaciofluvial deposits: A review. Earth-Science Reviews 97(1-4): 133-146, DOI 10.1016/j.earscirev.2009.09.001.

Trauerstein M, Lowick S, Preusser F, Rufer D and Schlunegger F, 2012. Exploring fading in single grain feldspar IRSL measurements. Quaternary Geochronology 10: 327-333, DOI 10.1016/j.quageo.2012.02.004.

Trautmann T, Krbetschek MR, Dietrich A and Stolz W, 2000. The basic principle of radioluminescence dating and a localized transition model. Radiation Measurements 32(5-6): 487-492, DOI 10.1016/S1350-4487(00)00119-0.

Tsukamoto S, Denby PM, Murray AS and Botter-Jensen L, 2006. Timeresolved luminescence from feldspars: New insight into fading. Radiation Measurements 41(7-8): 790-795, DOI 10.1016/j.radmeas.2006.05.013.

Wallinga J, 2002a. On the detection of OSL age overestimation using single-aliquot techniques. Geochronometria 21: 17-26.

Wallinga J, 2002b. Optically stimulated luminescence dating of fluvial deposits: a review. Boreas 31(4): 303-322, DOI 10.1111/j.15023885.2002.tb01076.x.

Wintle AG, 1973. Anomalous Fading of Thermoluminescence in Mineral Samples. Nature 245(5421): 143-144, DOI 10.1038/245143a0.

Wintle AG and Murray AS, 2006. A review of quartz optically stimulated luminescence characteristics and their relevance in singlealiquot regeneration dating protocols. Radiation Measurements 41(4): 369-391, DOI 10.1016/j.radmeas.2005.11.001. 